\title{
De homeostatische bevolkingsreeks voor Amsterdam in 1586-1865 toegelicht en getoetst
}

\author{
Hubert Nusteling
}

TSEG $15(1): 31-65$

DOI: $10.1835^{2} /$ TSEG.1016

\begin{abstract}
The contribution concerns the homeostatic method, as applied for construing an Amsterdam population series from 1586 to 1865 , and the criticism which it received. The method has been based on extrapolation of population numbers from one interval with a known population total (count) to another with the use of a series of fertile marriages. So, it implies that, in the Ancient Regime, an almost constant relationship existed between successive generations of married women in their fertile years (weighted fertile marriages) and the size of the population, to which they belonged. Due to changing quotes of remarriages as a consequence of changing mortality, series of first marriages are preferred. Whatsoever the causes of differences or divergences between marriage series may be, adequate corrections are required for applying different series successively. When combined, they ought to be consistent. The critics, however, totally neglect this prescript.
\end{abstract}

\section{Inleiding}

In Welvaart en werkgelegenheid in Amsterdam 1540-1 86o heb ik een dertig jaar geleden op basis van - grotendeels onder leiding van de vroegere stadsarchivaris Simon Hart opgestelde - huwelijksstatistieken voor Amsterdam in de periode $1586-1865$ bevolkingstotalen per interval van vijf jaar gepresenteerd. ${ }^{1}$ De resultaten lieten zien dat Amsterdam, toen het zich met de Alteratie van 1578 aan de kant van de Opstand tegen Phi-

1 H.P.H. Nusteling, Welvaart en werkgelegenheid in Amsterdam 1540-1 860. Een relaas over demografie, economie en sociale politiek van een wereldstad (Amsterdam/Dieren 1985). Zie ook: H.P.H. Nusteling, 'Kritische beschouwingen aangaande de Amsterdamse volkstellingen in de periode 1795-1859', Economisch- en Sociaal-Historisch Jaarboek 55 (1992) 189-235. 
lips II schaarde, zich van centrum van Holland tot metropool van een gebied ver daarbuiten heeft ontwikkeld. De opgang zou bijna een eeuw zonder onderbreking duren. Het inwonertal groeide van rond 30.000 naar meer dan 206.000 inwoners in 1672 . In de daaropvolgende halve eeuw boekte de stad nog wel vooruitgang, maar omstreeks 1735 waren met ten naaste bij 240.000 ingezetenen de grootste omvang en de hoogste commerciële machtspositie bereikt. De koopkracht van de bevolking was toen hoger dan ooit tijdens het Ancien Regime. De jaren die volgden verliepen voor handel en nijverheid ongunstig. Kort na 1750, in het bestek dus van vijftien jaar, was Amsterdams inwonertal naar iets meer dan 200.000 gedaald, hetgeen minder was dan in 1672 . Weliswaar steeg het bevolkingstotaal nog tot ruim 230.000 ingezetenen in 1790, maar de voorheen onaantastbare positie als handelsplaats was verloren gegaan. De inlijving van heel Nederland bij het Franse rijk in de jaren 1810-1813 bracht Amsterdam met circa 180.00o inwoners in zijn welvaart op een absoluut dieptepunt. Pas na 186o zou het inwonertal van 1735 worden bereikt om in de twintigste eeuw ver daarboven uit te stijgen.

Aan deze inleiding zou vermoedelijk niet veel toe te voegen zijn geweest, wanneer Marco H.D. van Leeuwen en James E. Oeppen destijds, in verschillende hoedanigheid aan de Cambridge Group for the History of Population and Social Structure gelieerd, niet met een alternatieve bevolkingsreeks op mijn inwonertallen voor Amsterdam hadden gereageerd. In een gezamenlijke artikel publiceerden ze naast schattingen omtrent de mortaliteit, migratie, vruchtbaarheid en leeftijdsopbouw een bevolkingsreeks voor Amsterdam vanaf het einde van de zeventiende eeuw tot het begin van de twintigste eeuw. ${ }^{2} \mathrm{Zij}$ hanteerden daarbij de Generalized Inverse Projection (GIP), een versie van de methode die de Cambridge Group eerder had gebruikt om een lange bevolkingsreeks voor Engeland te construeren. ${ }^{3}$ Volgens Van Leeuwen en Oeppen opent hun artikel de weg 'for later substansive interpretations of Amsterdam demography'. ${ }^{4} \mathrm{Bij}$ die gelegenheid schoven ze de homeostatische methode en daarop berustende inwonerreeksen als onbetrouwbaar aan de kant. Het laatste gebeurde expliciet ten aanzien van Amsterdam en impliciet voor de homeostatische bevolkingsreeks van Engeland, waarvan men in Cambridge wist dat ze in verschillende opzichten fors van de eigen be-

\footnotetext{
2 M.H.D. van Leeuwen, J.E. Oeppen, 'Reconstructing the demographic regime of Amsterdam 16811920 ' Economic and Social History in the Netherlands 5 (1993) 61-102.

3 E.A. Wrigley en R.S. Schofield, The population history of England 1541-1871 (Cambridge 1981).

4 Van Leeuwen en Oeppen, 'Reconstructing', 61. Voor hun reconstructie maken de auteurs gebruik van door mij gepubliceerde doop- en begrafenisreeksen.
} 
volkingsreeks verschilde. ${ }^{5}$ In deze bijdrage acht ik het daarom van belang de opzet, plaats en achtergronden van mijn (homeostatische) methode overzichtelijk voor te stellen en de op die methode gebaseerde bevolkingsreeks voor Amsterdam tegenover de uitgeoefende kritiek van deze twee auteurs uiteen te zetten. ${ }^{6}$ Daarmee verdedig ik op methodisch vlak tevens de betrouwbaarheid van mijn bevolkingsreeks voor Engeland.

\section{Oude bevolkingsreconstructies aan de hand van doop- aantallen}

Tot voor enige decennia was men gewoon veranderingen in de omvang van een bevolking vóór 1800 aan de hand van doop-, c.q. geboorteaantallen vast te stellen. Zo deden dat N.W. Posthumus voor Leiden ${ }^{7}$ en G.J. Mentink en A.M. van der Woude in hun studie over de demografie van Rotterdam. ${ }^{8}$ Ook maakt Van der Woude in zijn dissertatie ${ }^{9}$ over Holland ten noorden van het IJ in de zeventiende en achttiende eeuw tot dat doel uitgebreid gebruik van dooptellingen, uitgaande van een geboorteniveau van normaal 35 per 1000 inwoners met uitschieters tussen 30 en 40 promille. Naar diens mening weerspiegelden doop-, c.q. geboorteaantallen de loop van de bevolking van een gebied beter dan het met sterfte- en huwelijksstatistiek mogelijk zou zijn. Zo concludeerde hij dat Amsterdam omstreeks 168 o een omvang had verkregen die bij beperkte fluctuaties tot de volkstelling van 1795 , toen de stad 217.000

5 H.P.H. Nusteling, 'English population statistics for the first half of the nineteenth century: A new answer to old questions', in: Annales de démographie historique (Parijs 1993) 171-179, en H.P.H. Nusteling, 'The population of England (1539-1873) An issue of demographic homeostasis', Histoire et Mesure 8 (1993) 67-7o.

6 De enige wijziging in dit artikel ten opzichte van de eerder gepubliceerde bevolkingsgegevens is dat ophoging van de inwonertallen voor 1796-1865 op grond van hoge aantallen onwettige kinderen achterwege is gelaten, zodat de uitkomsten voor 1796-1865 in Bijlage 1 gemiddeld o,9 procent lager zijn dan de cijfers destijds. Het gaat hier om de bevolkingsreeksen in: H.P.H. Nusteling, 'La population d'Amsterdam de la fin du Xvıe siècle au début du xıxe siècle. Une méthode de reconstitution', Population 41:6 (1986) 961-977, betreffende de periode 1591-1810. Nusteling, Welvaart en werkgelegenheid, 240-241, omvat de jaren 1586 tot 1865 .

7 N.W. Posthumus, Geschiedenis van de Leidsche lakenindustrie ('s-Gravenhage 1939).

8 G.J. Mentink en A.M. van der Woude, De demografische ontwikkeling te Rotterdam en Cool (Rotterdam 1965).

9 A.M. van der Woude, Het Noorderkwartier (Wageningen 1972) 167-179, 624-633, 777-786, 788-79o, 792-794. 
tot 221.000 inwoners telde, gehandhaafd bleef. ${ }^{10}$ Deze benadering gaat voorbij aan wijzigingen in het geboorteniveau, waarom enige reserve geboden zij. Zelf heb ik voor Nijmegen ooit een dergelijke constructie uitgeprobeerd ${ }^{11}$ en het probleem was toen welke geboortecijfers bij de beschikbare doopreeksen te gebruiken om bevolkingsaantallen voor die stad vast te stellen. Voor Amsterdam heb ik een antwoord gevonden met de homeostatische methode, waarmee ik - anders dan Van der Woude hierboven - voor die stad in 168 o op 191.000 inwoners en in 1735 op een bevolkingstotaal van 239 .00o uitkom.

\section{Een homeostatische methode steunend op huwelijken}

Bij het zoeken naar betrouwbare geboortecijfers voor Amsterdam rees de gedachte dat veranderingen in het geboortecijfer te traceren zijn aan de hand van het kindertal per huwelijk. Een vaste verhouding [=c] tussen het geboortecijfer en het kindertal voor de vruchtbare huwelijken in een bepaald interval (van 5 jaar) wordt verondersteld. Dit houdt evenwel in dat de groep vruchtbare huwelijken $\left[=\mathrm{vh}_{\mathrm{i}}\right]$ een vaste verhouding ten opzichte van de totale bevolking bezit, waarbij een gegeven bevolkingstotaal met behulp van (een reeks) vruchtbare huwelijken terug in het verleden of omgekeerd naar het heden toe kan worden geëxtrapoleerd.

Het gaat om de volgende verhoudingen:

a. geboortecijfer gc $_{\mathrm{i}}[=$ aantal geboorten per jaar per 1000 inwoners $]=\left(\mathrm{ga}_{\mathrm{i}} / 5\right)^{*}\left(1000 / \mathrm{bev}_{\mathrm{i}}\right)$. Hierbij is bev $_{\mathrm{i}}$ het gemiddeld bevolkingstotaal van een vijfarig interval, $\mathrm{ga}_{\mathrm{i}}$ is het geboorteaantal per 5 jaar, dat door 5 moet worden gedeeld om het op jaarbasis te brengen. In de berekeningen wordt ga $\mathrm{i}_{\mathrm{i}}$ gelijkgesteld aan $\mathrm{da}_{\mathrm{i}}$ [= doopaantallen]. Dus gc $\mathrm{i}_{\mathrm{i}}=\left(20{ }^{*} \mathrm{ga}_{\mathrm{i}}\right) / \mathrm{bev}_{\mathrm{i}}=\left(200 * \mathrm{da}_{\mathrm{i}}\right) / \mathrm{bev}_{\mathrm{i}}$.

b. $\quad$ kindertal per huwelijk $=\mathrm{da}_{\mathrm{i}} / \mathrm{vh}_{\mathrm{i}}[=$ vruchtbare huwelijken, waarvan onder punt $\mathrm{d}$ een nadere omschrijving volgt]. Het ongetrouwd bevallenvan een kind was maatschappelijkonbehoorlijk.

c. verondersteld is een constante verhouding tussen het geboortecijfer en het kindertal per huwelijk: $\mathrm{gc}_{\mathrm{i}}=\left(20 \mathrm{o}^{*} \mathrm{da}_{\mathrm{i}}\right) / \mathrm{bev}_{\mathrm{i}}=\mathrm{c} * \mathrm{da}_{\mathrm{i}} /$

10 Ibidem, 191, 232.

11 H.P.H. Nusteling, Binnen de vesting Nijmegen. Confessionele en demografische verhoudingen ten tijde van de Republiek (Zutphen 1979) 41. Een recente aanvulling is H. Nusteling, 'Burgers en soldaten in Nijmegen ten tijde van de Republiek. Een demografische studie', in: Numaga.Jaarboek 62 (2015) 37 -73. 
$\mathrm{vh}_{\mathrm{i}}$ en vereenvoudigd $\mathrm{vh}_{\mathrm{i}} / \mathrm{bev}_{\mathrm{i}}=\mathrm{c} / 200=\mathrm{c}^{\prime}$. In de laatste vergelijking is dus $\mathrm{da}_{\mathrm{i}}$, dat staat voor het aantal kinderen, verdwenen. Het constant blijven van de verhouding $\mathrm{vh}_{\mathrm{i}} / \mathrm{bev}_{\mathrm{i}}$, weergegeven met c', sluit aan bij de constatering door G.J. Stolnitz ${ }^{12}$ dat in door hem onderzochte perioden in achttiende en negentiende eeuw een nauw verband bestond tussen de trends van geboortecijfers en die van de bruto reproductieratio's (= aantal kinderen voor vrouwen in de vruchtbare leeftijd tot 44 jaar).

d. Een verschil is wel dat de formule van Stolnitz in principe alle volwassen vrouwen in die leeftijdsgroep omvat en dat bij mij de vrouwen die niet trouwden, per definitie buiten beschouwing blijven. De vruchtbare huwelijken zijn namelijk als volgt berekend: $\mathrm{vh}_{\mathrm{i}}$ $=\left(o_{i}+1,86 * o_{i-1}+1.15 * o_{i-2}+0,36 * o_{i-3}\right) / 4,37$. Onder $o_{i}$ worden de ondertrouwen als proxy voor huwelijken in een bepaald interval van 5 jaar verstaan en onder o met de toevoegingen i-1, i-2 of i-3 respectievelijk de aantallen ondertrouwen in de drie eraan voorgaande intervallen. De voor de vier intervallen gebruikte wegingsfactoren $(1 ; 1,86 ; 1,15 ; 0,36)$ zijn vastgesteld door de bijdragen in de geboorten te berekenen, afhankelijk van de leeftijd van de vrouwen en van de duur van hun huwelijk, en door de onder de gehuwden in het midden van de negentiende eeuw optredende sterfte te verdisconteren. De lengte van de generaties is op 20 jaar gesteld. Omdat conform Pierre Goubert (zie hieronder) is uitgegaan van een vruchtbare-huwelijksduur van vijftien jaar, is het gewicht van $o_{i}$ en $o_{i-3}$ tot de helft gereduceerd. Veranderingen in de mortaliteit zijn niet in de formule verwerkt. Omdat in de overgang van de zeventiende naar de achttiende eeuw de sterfte, waarmee de mate van hertrouwen een nauw verband vertoonde, sterk daalde, dient in berekeningen van de bevolking in die periode van eerste huwelijken te worden uitgegaan. ${ }^{13}$

Voor het idee van een parallelle ontwikkeling tussen geboortecijfer en kindertal per huwelijk dank ik veel aan Pierre Goubert met diens baanbrekende dissertatie Beauvais et le Beauvaisis de 1600 à $1730 .{ }^{14}$ In die

12 G.J. Stolnitz, 'Uses of crude vital rates in the analysis of reproductivity',Journal of the American Statistical Society 50 (1955) 221.

13 Voor verdere gegevens zie: Nusteling, Welvaart en werkgelegenheid, 25-34.

14 P. Goubert, Beauvais et le Beauvaisis de 1600 à 1730 (Parijs 1960). In verkorte vorm onder de titel Cent mille provinciaux au xviie siècle (Parijs 1968). 
studie toont Goubert aan dat er omstreeks 1700 in de stad Beauvais en het omliggende platteland een stationair demografisch evenwicht bestond met de vruchtbaarheid van getrouwde vrouwen als centraal gegeven. De gemiddelde vruchtbaarheidsduur was vijftien jaar, doordat ze gewoonlijk op een leeftijd van 26 jaar trouwden en, wanneer hun huwelijk niet door het overlijden van henzelf of van hun partner voortijdig werd beëindigd, normaal op 41-jarige leeftijd hun laatste kind kregen. Deze vrouwen brachten gemiddeld zeven tot acht kinderen ter wereld, ofschoon vanwege de sterfte voor alle gehuwde vrouwen het gemiddelde kindertal vier à vijf kinderen bedroeg. De mortaliteit onder jonge kinderen was bovendien dusdanig dat slechts de helft van hen - dat wil zeggen circa 2,25 kinderen per gehuwde vrouw - volwassen werd en de plaats van de ouders kon overnemen. Een stabiele bevolkingsomvang werd gehandhaafd; 10 procent van de nieuwe generatie bleef vrijgezel of vertrok naar elders. Goubert constateerde ook dat in de stad Beauvais meer dan 15 procent van de vrouwen ouder dan 44 jaar nooit was getrouwd.

\section{Nuptialiteit}

Een en ander is kenmerkend voor de huwelijksmarkt in het vroegmoderne Europa. Vrouwen stelden bij dalende sterfte het huwelijk enige tijd (of voorgoed) uit en baarden minder kinderen. Hogere sterfte bevorderde een omgekeerde trend. Mannen waren voor hun huwelijkskansen allereerst van de arbeidsmarkt afhankelijk. Ze dienden over voldoende inkomen te beschikken om vrouw en kinderen - naar hun stand - te kunnen onderhouden. Aldus leidde inkrimping van de werkgelegenheid tot vertrek van jongeren, terwijl groei van de werkgelegenheid het stichten van gezinnen en ook vestiging van nieuwkomers stimuleerde. In het aantal huwelijkssluitingen komen dus wisselingen in de migratiestromen eveneens tot uitdrukking. In de vroegmoderne samenleving functioneerde het huwelijk als centraal demografisch regelingsmechanisme. Regel was dat voortplanting uitsluitend binnen het huwelijk was toegestaan. Over het algemeen werden er weinig buitenechtelijke kinderen geboren; in steden als Amsterdam en Rotterdam normaal niet meer dan 2 procent. Alleen bij zeer slechte economische, buitensporig zware omstandigheden, zoals rond 1810 , was het percentage aanmerkelijk hoger. ${ }^{15}$ 


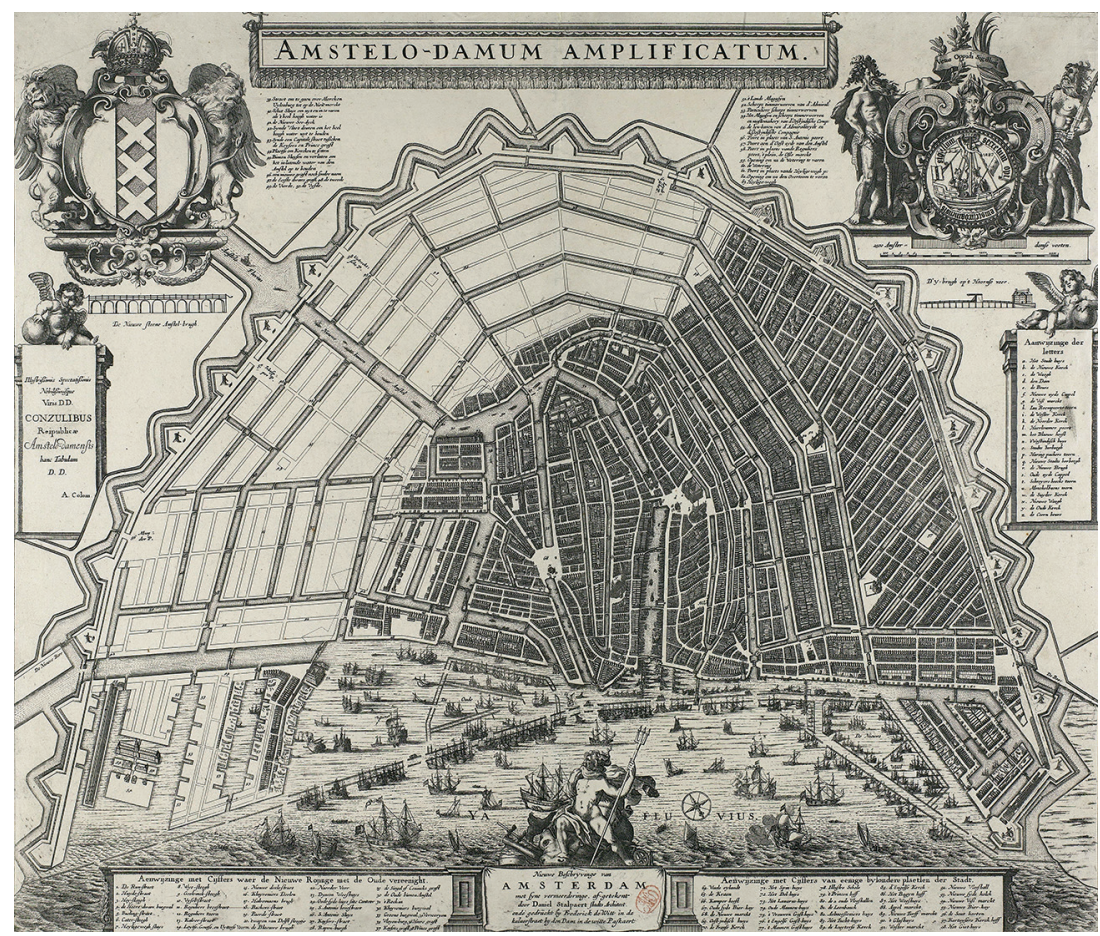

Illustratie 1 Plattegrond van Amsterdam met ontwerp voor de Vierde Uitleg, A. Besnard, Daniel Stalpaert, in of na ca. 1663-1682 (bron: Rijksmuseum RP-P-AO-20-33).

Geboortebeperking binnen het huwelijk was niet geaccepteerd. Met de demografische transitie begon omstreeks 187 o het oude vruchtbaarheidspatroon echter te veranderen.

Als gevolg van de geschetste levenshouding was het vrijgezellenbestaan in het Westen sterk verspreid. In Engeland was volgens de census van 185111 procent van de vrouwen van 40 tot 44 jaar nooit gehuwd. ${ }^{16}$ Te Amsterdam met zijn grote vraag naar vrouwelijk personeel was het percentage voor die categorie toen bijna 22, terwijl slechts 12,7 procent van de mannen van die leeftijd vrijgezel was, een verschil dat ten dele zijn verklaring vindt in de over het algemeen hogere sterfte onder jongens. Verspreide gegevens lijken erop te duiden dat in het westen van het Europese continent tot voorbij het midden van de negentiende eeuw rond 15 procent van de vrouwen van over 40 jaar ongetrouwd waren. Tot 
omstreeks 1870 was geboortebeperking binnen het huwelijk geen usance, maar toen begonnen bij een dalend sterfteniveau echtparen hun kindertal te beperken in plaats van het huwelijk uit te stellen. Het overgangsproces verliep geleidelijk, aangezien rond 196o in West-Europa van de vrouwen van begin 40 jaar nog altijd 10 procent vrijgezel waren tegen 6 procent in Engeland. Desondanks contrasteerde dat nog scherp met de minieme percentages ongehuwde vrouwen in de niet-Westerse wereld. ${ }^{17}$ Mogelijk onderscheidt de periode 1690 tot 1860 zich van de voorgaande en volgende jaren door een - ruw geschat -2 à 3 procent lagere nuptialiteit. In ieder geval tekenden zich op het eind van de zeventiende eeuw bepaalde demografische tendensen af. In Holland - maar ook elders - vielen een markante daling van de voorheen grote sterfte en een verhoging van de huwelijksleeftijd voor vrouwen te bespeuren. Tezelfdertijd werd de seksuele moraal strenger en harder en verminderde het aantal buitenechtelijke geboorten. ${ }^{18}$

\section{Leeftijdsopbouw en fertiliteit}

Traditioneel werd vóór 1870 de fertiliteit, de vruchtbaarheid van een bevolking, bepaald door het aantal vrouwen in de huwbare leeftijd en de mate waarin zij trouwden (nuptialiteit) of vrijgezel bleven. Bij een eerdere gelegenheid heb ik door simulatie berekend dat het aandeel van vrouwen in de leeftijd van 20 tot 40 jaar, dat zijn nagenoeg de vrouwen die de kinderen baarden, ondanks ingrijpende veranderingen van geboorte- en sterfteniveaus binnen een bevolking weinig veranderde. Over bijna een eeuw bleven de verschuivingen van het aandeel binnen een range van gemiddeld bijna 2 procent. ${ }^{19}$

Tabel 1 bevat gegevens van een simulatie om de constantheid van het aandeel van vrouwen in de vruchtbare jaren bij eenzijdige veranderingen in de fertiliteit te meten. Ze gaat uit van de leeftijdsopbouw van de vrouwelijke bevolking van Engeland in $1821-1881 .{ }^{2 \circ} \mathrm{De}$ o-19-jarige meisjes maakten daarvan 45,12 procent uit, de vrouwen in de

17 Voor 1960 zie: J. Hajnal, in: D.V. Glass en D.E.C. Eversley (eds.), Population in history. Essays in historical demography (Londen 1965) 101-143.

18 H. Nusteling, 'De bevolking: van raadsels naar oplossingen', in: Geschiedenis van Dordrecht van 1572 tot 1813 , deel II (Hilversum 1998) 93-96.

19 Zie: Nusteling, 'Fertility in historical demography', 137-138, Table 5, sub 4b.

20 Berekend naar B.R. Mitchell en Ph. Deane, Abstract of British historical statistics (Cambridge 1962) 11-12. 
Tabel 1 Leeftijdsopbouw van vrouwen in procenten bij fertiliteitsdaling (simulatie)

\begin{tabular}{|c|c|c|c|c|c|}
\hline Cohort & $\begin{array}{l}\text { Aanvangs- } \\
\text { percentage }\end{array}$ & $\mathrm{Na} 20$ jaar & $\mathrm{Na} 40$ jaar & $\mathrm{Na} 60$ jaar & $\mathrm{Na} 80$ jaar \\
\hline \multirow[t]{3}{*}{$0-19 \mathrm{jr}}$. & \multirow[t]{3}{*}{$45,12 \%$} & 40,61 & 34,02 & 30,82 & 29,46 \\
\hline & & $\left(=30,35^{*} 1,4867^{*} 0,9\right)$ & $\left(=28,60 * 1,4867^{*} 0,8\right)$ & $\left(=25,91^{*} 1,4867^{*} 0,8\right)$ & $\left(=24,77^{*} 1,487^{*} 0,8\right)$ \\
\hline & & $\rightarrow 42,52 \%$ & $\rightarrow 38,52 \%$ & $\rightarrow 36,82 \%$ & $\rightarrow 37,17 \%$ \\
\hline \multirow[t]{3}{*}{$20-39 \mathrm{jr}}$. & \multirow[t]{3}{*}{$30,35 \%$} & 30,35 & 28,60 & 25,91 & 24,77 \\
\hline & & & $(=42,52 / 1,4867)$ & $(=38,52 / 1,4867)$ & $(=36,82 / 1,4867)$ \\
\hline & & $\rightarrow 31,78 \%$ & $\rightarrow 32,38 \%$ & $\rightarrow 30,96 \%$ & $\rightarrow 31,25 \%$ \\
\hline \multirow[t]{3}{*}{ 240 jr. } & \multirow[t]{3}{*}{$24,54 \%$} & 24,54 & 25,70 & 26,97 & 25,03 \\
\hline & & & $(=31,78 * 0,8086)$ & $(=32,38 * 0,8086)$ & $(=30,96 * 0,8086)$ \\
\hline & & $\rightarrow 25,70 \%$ & $\rightarrow 29,10 \%$ & $\rightarrow 32,22 \%$ & $\rightarrow 31,58 \%$ \\
\hline Totaal & $100 \%$ & $95,50 \rightarrow 100 \%$ & $88,3 \rightarrow 100 \%$ & $83,70 \rightarrow 100 \%$ & $79,26 \rightarrow 100 \%$ \\
\hline
\end{tabular}

vruchtbare leeftijd van 20 tot 39 jaar 30,35 procent en de vrouwen van 40 jaar en ouder 24,54 procent. Driekwart van de vrouwelijke bevolking was dus jonger dan 40 jaar. Bovendien is aangenomen dat de sterfte binnen en tussen de leeftijdsklassen steeds hetzelfde bleef en dat de verlaging van de vruchtbaarheid met 20 procent geleidelijk in de eerste twintig jaar haar beslag kreeg. Het aandeel van de meisjes jonger dan 20 jaar daalde daarmee na de eerste 20 jaar per saldo met 10 procent. Pas voor de volgende intervallen geldt een 20 procent lagere fertiliteit voor alle vrouwen van 20 tot 40 jaar. Voor het overige zijn de oorspronkelijke verhoudingen tussen de cohorten ongewijzigd. Dat betekent dat bij de heersende mortaliteit en migratie de tweede leeftijdsklasse (die van de 20-39-jarigen) twee derde $[=0,6727=30,35 / 45,12]$ van de jongste leeftijdsklasse in het vorige interval uitmaakt (zie tabel 1 voorgaande kolom) en de derde en oudste leeftijdsklasse (van 40 jaar en ouder) niet meer dan $80,86(=24,54 / 30,35)$ procent van de middengroep van 20 jaar eerder. De omvang van klasse $0-19$-jarigen is zonder verandering van de fertiliteit $1,4867(=45,12 / 30,35)$ maal zo groot als de leeftijdsklasse 20-39-jarigen in hetzelfde interval. De uitkomst van de jongste groep wordt na de eerste 20 jaar vanwege de verlaagde fertiliteit verminderd met 10 en in de volgende perioden met 20 procent. De berekeningen van de globale cijfers die aldus zijn verkregen, zijn in tabel 1 weergegeven. Daarnaast zijn de verhoudingen tussen de drie onderscheiden leeftijdsklassen zodanig aangepast dat ze samen op 100 procent uitkomen, zoals aan de hand van de achter een pijltje geplaatste cijfers in de kolommen is vast te stellen. 
Uit de tabel valt af te leiden dat het geboortecijfer na 80 jaren met ongeveer 18 procent is gedaald: het aandeel van de jongste leeftijdsklasse is verminderd van 45,12 tot 37,17 procent. Het bevolkingstotaal is ondertussen tot bijna de helft gereduceerd. Anderzijds zagen de vrouwen van 40 jaar en ouder hun aandeel toenemen van 24,54 naar $31,5^{8}$ procent. Voor ons doel zijn vooral de uitkomsten voor de 20 - tot 40-jarige vrouwen van belang en door de jaren heen blijken ze 31,34 procent van de totale vrouwelijke bevolking te hebben uitgemaakt bij een gemiddelde absolute afwijking van 0,59 procent ten opzichte van de ijkpunten om de 20 jaar. Dat houdt een relatief verschil in van $1,78(=0,59 / 31,34)$ procent. Een afwijking van dien aard moet dan ook gelden voor de bevolkingsaantallen die met het aandeel van 20 - tot 39 -jarige vrouwen worden geëxtrapoleerd.

De analyse van onze methode gaat evenwel niet uit van vrouwen in de huwbare leeftijd, maar van vrouwen die in een periode van 20 jaar trouwden. Om die reden is het goed te weten in welke mate er een vaste verhouding bestaat tussen de huwelijken en de groep vrouwen van 20 tot 40 jaar. Anders gezegd, in hoeverre wordt de waarneming van het aantal vrouwen binnen het cohort van 20 tot 40 jaar door middel van de (onder)trouwregistratie statistisch door wisselingen in de nuptialiteit beïnvloed? Een antwoord is alleen schematisch te geven. Vrouwen die gemiddeld niet op hun 24ste maar pas op de leeftijd van 27 jaar trouwden, waren effectief ongeveer 20 procent korter vruchtbaar. Het effect op de geboorten was echter groter, doordat vrouwen na hun 3 oste minder vruchtbaar zijn. Zolang het evenwel om uitstel en niet om afstel van het huwelijk handelt, zijn er methodisch geen ingrijpende problemen. De waarneming van de vrouwen via de (onder)trouwregistratie wordt dan vertraagd zodat zelfs bij daling van het geboortecijfer van 42 naar 34 promille de historische huwelijksreeksen nog een redelijk goede proxy kunnen zijn voor de aantallen vrouwen in de leeftijd van 20 tot 40 jaar zonder ernstige bezwaren voor de nauwkeurigheid van onze methode. Geen uitstel zonder enig afstel, waarbij schommelingen in het aandeel van vrouwen die ongetrouwd bleven onvermijdelijk zijn. Wanneer men de demografische overgang van 1860 naar 1960 als referentie neemt, toen de nuptialiteit mogelijk van 85 naar 90 procent steeg, valt bij extrapolatie van de bevolking over langere tijd een afwijking van plus of minus 2 tot 3 procent niet uit te sluiten. Dat storende effect kan evenwel door andere factoren zijn afgezwakt, bijvoorbeeld door verschuiving in het gewicht van de leeftijdscategorie 20- tot 40 -jarige vrouwen als gevolg van migratie. De toetsingen hierna duiden erop dat de nega- 
tieve invloeden van allerlei verschuivingen voor de bevolkingsreeks van Amsterdam beperkt waren. Daarom nemen we aan dat er voor de vroegmoderne tijd dank zij een intern evenwichtsmechanisme een vaste verhouding tussen de vruchtbare huwelijken en de bevolkingsomvang bestond en spreken we bij de constructie van onze inwonerreeksen van de homeostatische methode.

\section{Het belang van consistente huwelijksreeksen}

Ten slotte is er te wijzen op facetten van de sterfte die bij de extrapolatie van de bevolking door middel van huwelijksreeksen van invloed kunnen zijn. Tot het laatste kwart van de zeventiende eeuw was vanwege hoge sterfte het aandeel van weduwnaars en weduwen die hertrouwden groot. In relatie met (latere) perioden met aanmerkelijk lagere mortaliteit is het daarom noodzakelijk zich tot de huwelijken van de personen die voor de eerste keer trouwden, te beperken. Die gegevens verdienen over het algemeen de voorkeur. Immers zijn hertrouwende weduwnaars en weduwen al als man of vrouw bij hun eerste huwelijk geregistreerd en zo waargenomen. Wat dan ook, toepassing van de homeostatische

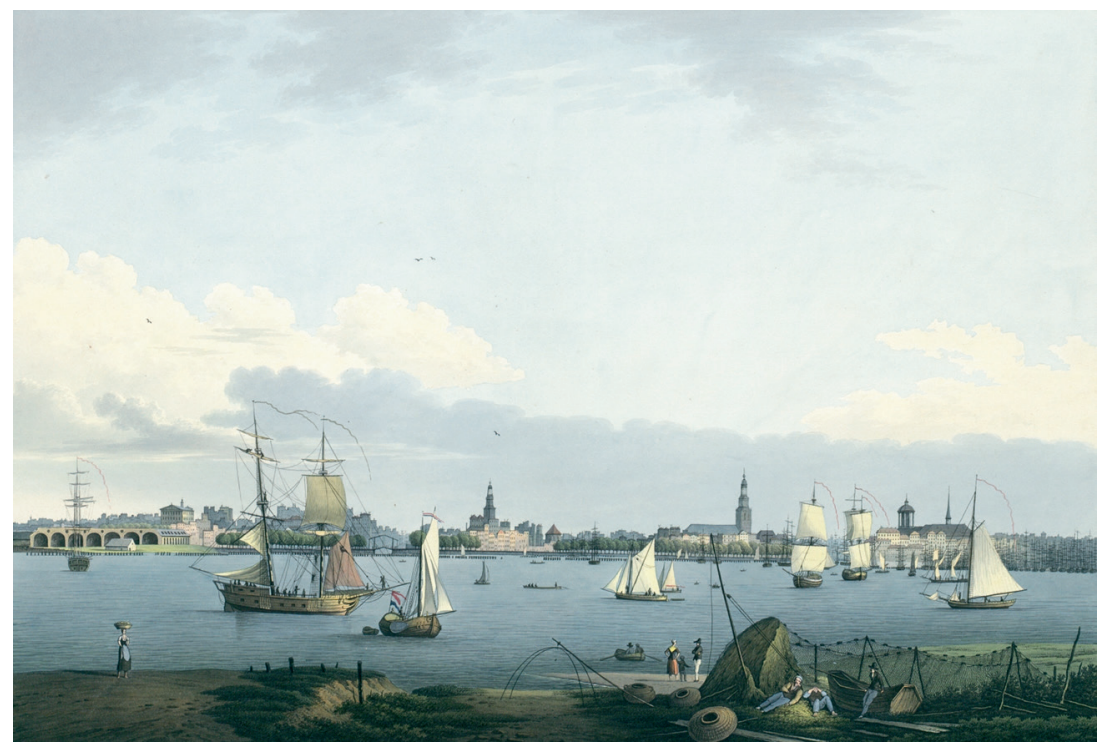

Illustratie 2 Vue du Port d'Amsterdam door Christian Gottlob Hammer (bron: Österreichische Nationalbibliothek. Is deel van: http://data.theeuropeanlibrary.org/Collection/a0492 Dataset:92070_Ag_EU_TEL_a0492_AustriaETravel). 
methode vereist consistente huwelijksreeksen die administratief op eenzelfde wijze en volgens een zelfde inhoudelijke definitie én samenstelling tot stand zijn gekomen. In dat geval is het tot circa 1870 mogelijk om met onze methode over langere tijd inwonerreeksen met afwijkingen van slechts een paar procent te construeren. Bij complicaties, zoals bij de wijzigingen die in 1811 in de manier en opzet van registreren plaatsvonden, is adequate aanpassing van de reeksen vereist. De demografische transitie, een verschijnsel dat met de dalende mortaliteit voor kinderen na het midden van de negentiende eeuw samenhangt, heeft meer ingrijpende gevolgen. Het veroorzaakte zodanige verschuivingen in de leeftijdsopbouw en wijziging van het voortplantingspatroon dat daardoor de homeostatische methode dan niet langer kan worden gebruikt.

\section{De constructie van één of van twee aaneensluitende be- volkingsreeksen}

Inzake de vereiste consistentie van de huwelijksreeksen hebben Oeppen en Van Leeuwen bij het toetsen van de homeostatische methode verstek laten gaan. In het algemeen geven ze de methode juist weer, maar dat is niet het geval bij de toepassing en toetsing ten aanzien van de huwelijksreeksen. Het principe dat de vruchtbare huwelijken (per interval van vijf jaar) van het eind van de zestiende eeuw tot voorbij het midden van de negentiende eeuw een vaste verhouding tot bevolkingsomvang bezitten, omschrijven ze zoals door mij geformuleerd. ${ }^{21}$ Voor de verhouding in de periode 1586-1810 stellen ze dat het inwonertal van Amsterdam normaal $23,467(=200 / 8,53)$ keer zo groot is als de waarden die zij voor de vruchtbare huwelijken aan de hand van de ondertrouwen voor eerste huwelijk (=oe) berekenden, terwijl voor de jaren 1811-1865 de inwonertallen het 23,324-voud zijn van de vruchtbare huwelijken die van de reeks alle huwelijken (= ha) zijn afgeleid. Destijds heb ik bij de twee opeenvolgende perioden voor verschillende constanten gekozen, om te laten zien dat de constructie van de bevolkingsreeksen op twee verschillende trouwreeksen berustte, te weten één lopend tot 1810 gebaseerd op de registratie van ondertrouwen voor eerste, ten dele elders voltrokken huwelijken en één voor de jaren erna van alle ter plaatse 'voor de wet' gesloten huwelijken. 
In Bijlage 1 ziet men dat voor 1586-1810 een constante verhouding van vruchtbare huwelijken ten opzichte van het inwonertal van 23,448 en voor $1810-1865$ een van 23,325 is gehanteerd. Qua omvang wijken de genoemde verhoudingen weinig van elkaar af, maar vanwege de verschillende soorten huwelijksreeksen waarop ze betrekking hebben, is dat ten dele toeval. ${ }^{22}$ De opeenvolgende toegepaste reeksen zijn proxies, benaderende waarden - die ten minste denkbeeldig parallel aan elkaar lopen - en dienen om de vruchtbare huwelijken te berekenen. De beide reeksen vruchtbare huwelijken hebben elk een eigen omrekeningsfactor ten opzichte van de bevolkingsreeks, die respectievelijk aan de hand van de volkstelling van 1622 en van een volkstelling uit het jaar 1828 is vastgesteld om de bevolkingsreeks van de eigen periode te bepalen.

Voor de periode tot 1810 is van de ondertrouwreeks eerste huwelijken $(=$ oe) uitgegaan vanwege de aanzienlijke vermindering van de mortaliteit in het laatste kwart van de zeventiende eeuw waarbij het aandeel hertrouwenden weduwen en weduwnaars navenant gereduceerd werd. ${ }^{23}$ In die omstandigheden beïnvloeden de aantallen alle ondertrouwen $(=\mathrm{oa})$ de nauwkeurigheid van de te berekenen inwonertallen zeer ongunstig. Om het inwonertal voor 1811-1865 te berekenen is evenwel de statistiek van alle huwelijken (ha) gehanteerd. Alleen daarvan is een doorlopende reeks voorhanden. Opgaven van de eerste huwelijken (= he) ontbreken van 1826 tot 185 o. Gebruik voor de periode na 1810 van de reeks alle huwelijken lijkt niet bezwaarlijk, omdat de verhouding tussen eerste en alle huwelijken voor zover bekend stabiel was. In 1811-1825 maakten qua aantal eerste huwelijken 86,5 procent van alle huwelijken uit tegen 85,1 procent in $185^{1-1865}$, dus gemiddeld 85,8 procent. Er is een verschil van o,8 procent, wanneer de inwonertallen in plaats van aan de hand van alle huwelijken maar met de statistiek voor het eerst gehuwden - uiteraard onder aanvulling van de ontbrekende jaren - worden berekend. Dus bij constructie van de inwonertallen zijn tot 1810 alleen ondertrouwen voor eerste huwelijk en voor de periode erna alle huwelijken of de eerste huwelijken te hanteren. Voorwaarde is dat de reeksen qua samenstelling consistent zijn en in principe (nagenoeg) parallel aan elkaar lopen en het verschil tussen die reeksen adequaat wordt verrekend. De vruchtbare huwelijken die tot 1810 op de statistiek van ondertrouwen voor eerste huwelijk (oe) berusten, zijn tot inwo-

22 Het geringe verschil van 0,5 is toeval daar de vruchtbare huwelijken in eerste periode met ondertrouwenvoor eerstehuwelijken zijn berekend en diein deperiode erna metalle ter plaatsegesloten huwelijken. 23 Zo bedroeg bij alle ondertrouwen het aandeel van bruiden en bruidegoms die voor de eerste keer trouwden 67,8 procent in 1621-1625 tegen 77,7 procent in 1791-1795. 
nertallen getransponeerd - we volgen voor zover mogelijk Oeppen en Van Leeuwen - met de omrekeningsfactor 23,448 (= 106500 [ bev $\left._{1621 / 5}\right]$ $/ 4542$ [vh(oe $\left.)_{1621 / 5}\right]$. Voor de jaren na 1810 zijn de vruchtbare huwelijken gebaseerd op de doorlopende reeks van alle huwelijken binnen de $\operatorname{stad}(=$ ha) en vermenigvuldigd met de constante $23,325(=202110$ [bev $\left.{ }_{1826-30}\right] / 8665\left[\operatorname{vh}(\text { ha })_{1826 / 30}\right] . .^{24}$

Voor de reconstructie van de inwonertallen in 1811-1825 zij nog opgemerkt dat de ondertrouwgegevens voor eerste huwelijk (oe) in de drie tijdsintervallen van 1796 tot 1810 in waarden zijn omgezet die aansluiten op de na 1810 beschikbare reeks alle huwelijken (ha) door de ondertrouwtotalen van de intervallen 1796-180o, 1801-1805 en 1806-181o te vermenigvuldigen met de factor 1,00533 ofwel $23,448 / 23,325 \cdot{ }^{25}$ De teller van de deling $(=23,448)$ wordt gevormd door de constante verhouding van de vruchtbare huwelijken tothet inwonertal voor de periode vóór 1810 , terwijl de constante voor 1811-1865 als noemer $(=23,325)$ fungeert. Binnen de statistiek is het aanvaarde praktijk vergelijkbare maar enigermate verschillend gedefinieerde reeksen op dusdanige wijze aan elkaar te koppelen.

\section{Twee-enig}

Naar analogie van de aanpassingen van de ondertrouwen in de jaren 1796-1810 om met eerste huwelijken de bevolking voor 1811-183o te berekenen, is ook een tot 1865 doorlopende (onder)trouwreeks te construeren. Daarmee zijn vruchtbare huwelijken tot 1865 te berekenen, die met dezelfde omrekeningsfactor als voor de periode tot 1810 , in een bevolkingsreeks voor de gehele periode 1586-1865 kunnen worden omgezet. De ondertrouwreeks voor eerste huwelijk (oe) wordt namelijk na 1810 voortgezet door de reeks alle gehuwden (ha) uit de jaren 1811-1865 met behulp van de factor $0,9948(=23.325 / 23,448$ of $=1 / 1,00533$ in de vorige alinea) aan te passen. De met deze reeks (oe) verkregen vruchtbare huwelijken geven gecombineerd met de daarbij behorende omrekeningsfactor 23,448 de bevolkingsreeks voor de gehele periode 1586-1865. De juistheid van deze alternatieve manier van berekenen is eenvoudig te bewijzen. Voor 1811-1865 $5^{26}$ geldt immers: bev ${ }_{1811 / 65}=\operatorname{vh}(\text { oe })_{1811-65} * 23,448=$

\footnotetext{
24 Het verschil van mijn constanten met die van Van Leeuwen \& Oeppen komt door afronding. 25 De uitkomsten van die bewerking naar waarden als van alle huwelijken zijn 7893,85 (1796-18oo), 7819,46 (1801-1805) en 7789,30 (1806-1810).

26 Hier en in de volgende aanduidingen staat 1811-1865 kortheidshalve voor de successieve waarden per interval van vijf jaar van bev $v_{i}$ en $v h(o e)_{i}$ en vh(ha) $)_{i}$.
} 
$\operatorname{vh}(\text { ha })_{1811-65} *(23,325 / 23,448)[=$ de aanpassingsfactor 0,9948 hierboven $]^{*} 23,448$. De laatste term in de vergelijking voor bev $_{1811-65}$ is ook te schrijven als vh(ha) ${ }_{1811-65} *\left(\left[23,325^{*} 23,448\right] / 23,448\right)$. Vereenvoudigd is het: bev $_{1811-65}=v h(h a)_{1811-65} * 23,325$, te weten de basisformule van de oorspronkelijke berekening van bevolkingstotalen van Amsterdam in 18111865, zoals in Bijlage 1 opgenomen. ${ }^{27}$

\section{Tabel 2 Verhoudingen tussen de verschillende ondertrouw- en huwelijksreeksen}
1. $0 a_{1606 / 25}=0 e_{1606 / 25} * 1,428$ (dus oe $\left.e_{1606 / 25}=0 a_{1606 / 25} * 0,70\right) ; 0 a_{1776 / 1805}=0 e_{1776 / 1805} * 1,292{\text { (dus } 0 e_{1776 / 1805}=}=$ oa $\left.{ }_{1776 / 1805}{ }^{*} 0,774\right) ;$ oorzaak van de discrepantie is een verandering in het sterfteniveau.
2. $h_{a}=h^{*} 1,16237$ (dus he $=$ ha $\left.* 0,86031\right)$.
3. oe $=h a * 0,99469$ (en ha $=0 e^{*} 1,00533$ ), d.m.v. volkstellingen vastgesteld (zie vorige paragraaf).
4. Uit oe ${ }_{1776 / 1805}=0 a_{1776 / 1805}{ }^{*} 0,774$ (zie onder 1) en oe $=$ ha $* 0,99469$ (zie onder 3) volgt 0a ${ }_{1776 / 1805}{ }^{*} 0,774=$ ha * 0,99469. Vandaar oa 1776/1805 $=$ ha * $(0,99469 / 0,774)=$ ha * 1,2851.
5. Anderzijds volgt uit oe $=$ ha * 0,99469 en ha $=$ he * 1,16237 dat oe $=($ he * 1,16237) * 0,99469 $=$ he * 1,1562.

oa $=$ ondertrouw, incl voor hertrouw; oe = ondertrouw voor eerste huwelijk; ha = alle huwelijken; he = eerste huwelijken.

Aldus is aangetoond dat het gebruik van de homeostatische methode met verschillende ondertrouw- of huwelijksreeksen is toegestaan, mits deze in werkelijkheid of tenminste in principe parallel aan elkaar lopen, met andere woorden onderling steeds eenzelfde verhouding bezitten. Eigen omrekeningsfactoren zijn daarbij noodzakelijk. Wie evenwel er de voorkeur aan geeft met een zelfde vaste verhoudingscijfer te werken om van vruchtbare huwelijken tot een bevolkingsreeks te geraken, dient bij gebruik van verschillende soorten trouwreeksen, zoals van ondertrouw (oe en oa) of van eerste (he) of alle huwelijken (ha), deze eerst door middel van adequate omrekeningsfactoren tot één consistente serie samen te voegen.

Eenvoudige vergelijkingen zijn voldoende om te concluderen dat voor Amsterdam sommige reeksen qua omvang sterk en een enkele zelfs zeer wisselend van samenstelling is. Zo blijkt de verhouding oa/ oe in $1606 / 1625$ gelijk aan 1,428 tegen 1,3 o in $1776-1805$, waarom we ons vóór 1810 tot de reeks oe hebben beperkt. De reeks ondertrouwen voor eerste huwelijken blijkt namelijk - in tegenstelling tot de reeks alle ondertrouwen - bij extrapolatie op basis van de census van 1622 voor 
1795 een uitkomst op te leveren die voortreffelijk met de volkstelling van dat jaar overeenkomt. Anders dan in de voorgaande periode is de verhouding van alle huwelijken tot de eerste huwelijken (ha/he) tussen 1811 en 188 o redelijk constant. Onder gebruikmaking van de volkstellingen in 1622 en in 1828 is nu in tabel 2 een overzicht opgesteld van de verhoudingen tussen de ondertrouwreeksen oa en oe en de huwelijksreeksen ha en he. Daar blijkt onder punt 4 dat de reeks alle ondertrouwen (oa) circa 180028,5 procent groter is dan de reeks alle huwelijken (ha), die na 1810 een aanvang neemt. Verder laat punt 5 zien dat de reeks ondertrouwen voor eerste huwelijk (oe) in 1810 de daarop volgende reeks eerste huwelijken (he) qua bereik met 15,62 procent overtreft. De verandering in de huwelijksadministratie met de invoering van de burgerlijke stand was statistisch bezien zeer ingrijpend. Wie de oude reeks oe aan de huwelijksreeksen van na de overgang wenst te koppelen, behoort dus voor de vereiste consistentie nauwgezet met de in tabel 2 weergegeven verhoudingen rekening te houden.

\section{De critici gecorrigeerd}

Aan de soms grote verschillen tussen de onderscheiden ondertrouw- en huwelijksreeksen zijn Van Leeuwen en Oeppen bij toetsing van de homeostatische methode geheel voorbijgegaan. Zonder enige aanpassing voegden zij de tot 1810 lopende reeks ondertrouwen voor eerste huwelijk (oe) tot één reeks met de reeks eerste huwelijken (he) uit de volgende decennia samen om met dezelfde reductiefactor voor beide onderdelen een bevolkingsreeks te construeren. Het verschil in bereik tussen de twee basisreeksen - ruim 15 procent (zie tabel 2, sub 5 ) - werd verwaarloosd. Bij een tweede toets regen ze alle ondertrouwen (oa) en alle huwelijken (ha) van vóór en na 1810, die onderling bijna 3 o procent verschillen, eveneens aan elkaar door ze simpelweg met een en dezelfde factor tot inwonertallen op te hogen. Het resultaat is bij voorbaat negatief. Wat blijkt bij nadere beschouwing? Compensatie voor de verschillen tussen ondertrouwen voor eerste huwelijken en van (alle en eerste) huwelij$\mathrm{ken}^{28}$ doet de uitkomsten van Van Leeuwen en Oeppen wél met mijn inwonertallen overeenstemmen. In tabel 3 zijn in de kolommen 1 en 3 de homeostatische resultaten zoals door hen berekend, met aanduiding van 
de gebruikte huwelijksreeksen te vinden. Daarnaast zijn er in de kolommen 2 en 4 de gecorrigeerde gegevens weergegeven die redelijk overeenkomen met mijn homeostatische inwonertallen in de allerlaatste kolom.

Tabel 3 Vergelijking van de bevolkingsaantallen voor Amsterdam op basis van homeostatistische methode, 1796-1875

\begin{tabular}{|c|c|c|c|c|c|}
\hline \multirow[b]{2}{*}{ Periode } & \multicolumn{4}{|c|}{ Homeostatische methode volgens Van Leeuwen en Oeppen } & \multirow[b]{2}{*}{$\begin{array}{l}\text { Homeostatische } \\
\text { methode } \\
\text { volgens } \\
\text { Nusteling }\end{array}$} \\
\hline & $\begin{array}{c}\text { Aantallen } \\
\text { obv. oe en he }\end{array}$ & $\begin{array}{c}\text { Aantallen } \\
\text { obv. correctie } \\
\text { Nusteling } \\
\left({ }^{*} 1,156\right)\end{array}$ & $\begin{array}{c}\text { Aantallen } \\
\text { obv. oa en ha }\end{array}$ & $\begin{array}{c}\text { Aantallen } \\
\text { obv. correctie } \\
\text { Nusteling } \\
\left({ }^{*} 0,770 \text { en }\right. \\
\left.{ }^{*} 0,995\right)\end{array}$ & \\
\hline $1796-1800$ & 209.000 & & 269.000 & 207.100 & 208.816 \\
\hline $1801-1805$ & 193.000 & & 250.000 & 192.500 & 192.874 \\
\hline $1806-1810$ & 185.000 & & 241.000 & 185.500 & 184.718 \\
\hline $1826-1830$ & $(177.000)$ & (203.843) & 202.000 & & 202.105 \\
\hline $1831-1835$ & $(177.000)$ & (203.759) & 202.000 & & 202.658 \\
\hline $1836-1840$ & $(179.000)$ & (205.529) & 206.000 & & 205.191 \\
\hline 1861-1865 & $(205.000)$ & (237.643) & 242.000 & & 240.689 \\
\hline $1866-1870$ & 212.000 & 245.008 & (249.401) & (248.104) & {$[248,083]$} \\
\hline $1871-1875$ & 223.000 & 257.771 & $(261.220)$ & $(259.862)$ & [259.839] \\
\hline
\end{tabular}

De aantallen tussen haakjes zijn niet door Van Leeuwen en Oeppen, maar wel conform de door hen gevolgde wijze met voor 1826-1840 geraamde eerste huwelijken, berekend. Voor de toegepaste correcties zie tabel 2, sub 5 $(1,156)$, sub $1(0,77)$ en sub $3(0,995)$. Correctiefactor 1,156: Van Leeuwen en Oeppen gaan voor de gehele periode uit van dezelfde reductiefactor 23,448 , die voor de periode tot 1810 geldt, zodat voor de periode erna de correctiefactor 1,156 (=oe/he) nodig is. Correctiefactoren 0,770 en 0,995: De bevolkingsaantallen zijn gebaseerd op samenvoeging van alle ondertrouwen $(=0$ a) tot 1810 en alle huwelijken $(=h a)$ erna, door middel van de factor 23,448. De correctiefactor voor de jaren tot 1810 is 0,7699 (= oa /oe). Voor de intervallen van 1866 tot 1880 geldt de factor 0,9948 vanwege het gebruik van de iets te hoge reductiefactor 23,448 in plaats van 23,325. Voor de jaren 1866-1880 zijn de bevolkingsaantallen van Nusteling tussen vierkante haakjes geplaatst omdat de gehanteerde homeostatische formule na 1865 niet langer te gebruiken is en deze gegevens slechts dienen ter vergelijking.

\section{Vergelijking met de negentiende-eeuwse volkstellingen}

Bij de beoordeling van de homeostatische methode concentreren Van Leeuwen en Oeppen zich op de periode vanaf 1795 met een hele reeks volkstellingen als toetssteen. Daarbij erkennen ze: 'The correspondence between his [Nusteling's] estimates and the 1795 total [= census] is very good, with a difference of only $2 \%$. Correspondence with the next censuses, as presented by Nusteling for the years $1806-186 \circ$, is generally very 
good too.' ${ }^{29}$ Tabel 4 laat zien dat mijn inwonertallen met uitzondering van die rond 1810, inderdaad goed met de negentiende-eeuwse volkstellingen overeenstemmen. De homeostatische methode blijkt, zoals ik vanwege de demografische transitie steeds heb benadrukt, voor het laatste derde deel van de negentiende eeuw en daarna niet meer gebruikt te kunnen worden. Daarom zijn de 'homeostatische' uitkomsten van na 186 o in tabel 4 tussen haakjes geplaatst. Voor $1795^{-1} 865$ verschillen mijn inwonertallen gemiddeld 2,5 procent van de corresponderende volkstellingen. Zonder de tellingen rond 1810 bedraagt de afwijking 1,4 procent. Ten opzichte van dezelfde, ongecorrigeerde volkstellingen vertonen de GIP-bevolkingstotalen gemiddeld eenzelfde verschil van 2,5 procent. ${ }^{3 \circ}$ De homeostatische reeks blijkt rond 181010 procent lager te zijn dan de volkstelling, terwijl de GIP-bevolking in 1815 met 9 procent de telling te boven gaat. ${ }^{31}$ Omstreeks 182 ovalt er een cesuur, daar in 1821-1865 de GIPreeks slechts 1,4 procent hoger uitkomt dan de homeostatische totalen.

$\mathrm{Al}$ eerder heb ik geprobeerd aan te tonen dat de volkstellingen van rond 1810 tijdens de Franse overheersing te hoog zijn en daarentegen de telling van 1815 vertrouwen verdient. ${ }^{32}$ De homeostatische inwonertallen zijn, het interval rond 1828 uitgezonderd, onafhankelijk van de volkstellingen tot stand gekomen, waarmee de berekende inwonertallen, afgezien van die voor de jaren omstreeks 1810, goed met elkaar overeenstemmen. De concordantie bewijst de betrouwbaarheid van beide soorten gegevens. Maar wat valt er te zeggen van de discrepantie rond 1810 ? De neergang in de homeostatische inwonertallen in de periode 1790-1813, van het begin van de Franse Revolutie tot het einde van de inlijving van Nederland bij Frankrijk, ging gepaard met een gestadige neergang van Amsterdams handel en economie, waarbij de koopkracht van de burgers in 1812 een dieptepunt bereikte. ${ }^{33}$ Over het algemeen toonden welvaart en armoede een directe relatie - positief en negatief met het inwonertal. In 1813 zal de stad daarom niet meer inwoners hebben geherbergd dan in 1815 . Een ander argument is dat bij een gelijkmatige interpolatie van de inwonertallen op basis van de volkstellingen van 1795 en 1815 er in 181 o hoogstens 186.000 mensen in Amsterdam woonden. Dit aantal wijkt royaal af van de ruim 200.000 ingezetenen

29 Ibidem, 94.

3 o Ibidem, 72 (tabel 3 ) en 73-74, met ongeveer 2 procent opgehoogde volkstellingen vóór 1859 .

31 Met 10 procent voor 1806-181o lopen beide reeksen eveneens sterk uiteen.

32 Nusteling, 'Kritische beschouwingen', 201-205.

33 Nusteling, Welvaart en werkgelegenheid, 264. 
Tabel 4 Vergelijking van de bevolkingsaantallen voor Amsterdam (volgens homeostatische en GIP-methode) met de volkstellingen, 1795-1878

\begin{tabular}{|l|c|c|c|c|c|c|}
\hline \multicolumn{4}{|c|}{ Bevolkingsaantallen ( 1.000) } & \multicolumn{3}{c}{ Verhouding } \\
\hline Jaar & $\begin{array}{c}\text { Homeostat. } \\
\text { methode }\end{array}$ & $\begin{array}{c}\text { GIP- } \\
\text { methode }\end{array}$ & Volkstelling & $\begin{array}{c}\text { Homeo/ } \\
\text { GIP }\end{array}$ & $\begin{array}{c}\text { Volkstel/ } \\
\text { Homeo }\end{array}$ & $\begin{array}{c}\text { Volkstel/ } \\
\text { GIP }\end{array}$ \\
\hline 1795 & 217,0 & 211,9 & $217,0-222,0$ & 1,024 & $1,0-1,023$ & $1,024-1,048$ \\
\hline 1810 & 181,9 & 202,3 & $201,0(1809-1810)$ & 0,899 & 1,105 & 0,994 \\
\hline 1815 & 179,0 & 198,2 & 180,1 & 0,903 & 1,006 & 0,909 \\
\hline 1820 & 184,7 & 196,5 & $191,5(1821)$ & 0,94 & 1,037 & 0,975 \\
\hline 1830 & 202,4 & 205,6 & $202,4(1829)$ & 0,984 & 1 & 0,984 \\
\hline 1840 & 209,3 & 210,9 & $211,2(1839)$ & 0,992 & 1,009 & 1,001 \\
\hline 1850 & 223,7 & 223,6 & $224,0(1849)$ & 1,001 & 1,001 & 1,002 \\
\hline 1860 & 237,4 & 239,6 & $243,3(1859)$ & 0,991 & 1,025 & 1,015 \\
\hline 1870$]$ & 254,0 & & $264,7(1869)$ & & {$[1,042]$} & \\
\hline$[1878]$ & 276,5 & & 305,8 (interpolatie) & & {$[1,106]$} & \\
\hline Gemiddelde afwijking in \% & & & & $2,50 \%$ & $2,50 \%$ \\
\hline
\end{tabular}

De homeostatische inwonertallen zijn (behalve voor 1878) gemiddelden van de intervallen rond de vermelde jaren (zie Bijlage 1). Het aantal voor 1878 is berekend door interpolatie op basis van de tellingen van 1869 en 1879. De gegevens voor 1870 en 1878 zijn tussen haakjes geplaatst omdat vanwege de demografische transitie de homeostatische formule minder bruikbaar is.

die er volgens de dubieuze volkstellingen van 1809 en 1811 waren. Het geïnterpoleerde inwonertal is meer in overeenstemming met de 181.900 inwoners in 1810 volgens de homeostatische methode.

Zonder veel toelichting stellen Van Leeuwen en Oeppen dat de volkstellingen van 1795 en 1859 voor Amsterdam betrouwbare resultaten verschaffen, maar dat de in de tussentijd gehouden tellingen - in het bijzonder die in de jaren 1811-1821 - weleens tot tien procent te laag zouden kunnen zijn. ${ }^{34}$ Dat zal de verklaring zijn waarom hun GIP-reeks voor 1815 van bijna 200.000 inwoners uitgaat in plaats van 180.000 ingezetenen conform de volkstelling van dat jaar, terwijl andere officiële tellingen wel worden gevolgd. Met hun bewering lijken ze zich aan de kant te scharen van Theo van Tijn die in zijn proefschrift Twintig jaren Amsterdam uit 1965 schrijft dat 'de bevolking van Amsterdam in de eerste helft der negentiende eeuw vrij wat groter was, dan de volkstellingen aangeven'. ${ }^{35}$

34 Van Leeuwen en Oeppen, 'Reconstructing', 75.

35 Th. Van Tijn, Twintig jaren Amsterdam. De maatschappelijke ontwikkeling van de hoofdstad van de jaren' 50 dervorige eeuw tot 1876 (Amsterdam 1965) 105. 
Van Tijns stellingname stoelt op de overtuiging dat de volkstelling in 1849 voor de hoofdstad ongeveer 10 procent te lage uitkomsten geeft. Hij liet zich daarbij leiden door berichten van de Amsterdamse buurtcollegien dat ze in de jaren $185^{\circ}$ meer dan 24.000 'inschrijvingen welke bij de volkstelling in 1849 door de belanghebbenden verzuimd waren' alsnog in hun registers hadden opgenomen. Om met Van Tijn die mededelingen als bewijs te beschouwen dat in 184910 procent van de bevolking buiten de officiële telling gebleven zou zijn, is voorbarig. Latere berichten melden namelijk dat aan de hand van de volkstelling van 1859 ruim 20.000 persoonsnamen uit de bevolkingsregisters zijn geschrapt. Het lijkt erop dat bij de eerdere aanvullingen van de registers onvoldoende rekening is gehouden met verhuizingen van de ene naar de andere buurt binnen de stad, zodat ze geen bewijs zijn van onvolledigheid van de uit 1849 en eerder daterende volkstellingen. ${ }^{36}$ Deze conclusie vindt steun in de onderlinge consistentie tussen de volkstellingen tot 1859 en de homeostatische bevolkingstotalen (zie tabel 4), die - afgezien van het interval 18261830 bij vaststelling van de verhouding tussen inwonertal en vruchtbare huwelijken - onafhankelijk van elkaar zijn. De GIP-aantallen, waarin als regel de uitkomsten van de volkstellingen verwerkt zijn, bezitten die onafhankelijkheid niet. ${ }^{37}$ In dat licht zijn vanwege de aanzienlijke discrepantie met de homeostatische reeks de volkstellingen van rond 1810, die ook om andere redenen minder aannemelijk zijn, van verdacht allooi..$^{3}$

\section{Kenmerken van de twee bevolkingsreeksen vóór 1810}

Waarom gaat de GIP-reeks, die als een beter substituut voor de van 1581 tot 1865 lopende homeostatische reeks is gepresenteerd, slechts tot 1681 en niet tot tenminste 1622 terug waarvoor een betrouwbare telling van de Amsterdamse bevolking bestaat? Oeppen erkent zelf het belang om de bevolkingsgrootte voor het begin en het einde van een reeks nauwkeurig te kennen. Bij beschikbaarheid van de tussentijdse natuurlijke aanwas (= het verschil tussen geboorten en sterfte) is dan het totale migratiesaldo (= het verschil tussen de aantallen immigranten en emigranten in een bepaalde periode), waarover in het algemeen weinig data

36 Nusteling, 'Kritische beschouwingen', 205-209. Het verschil van 4.000 (= 24.000 toegevoegde minus 20.0oo verwijderde namen) komt bij de volkstelling van 1849 neer op 1,65 procent en kan te maken hebben met een definitiewijziging in verband met vreemdelingen, waarvan in 1859 sprake is.

37 Van Leeuwen en Oeppen, 'Reconstructing', 69.

38 Nusteling, 'Kritische beschouwingen', 201-205, 210-214. 
bestaan, te berekenen. De bij de GIP-inwonertallen gebruikte gegevens omtrent de natuurlijke groei in de jaren 1681-1810 zijn van de door mij gepubliceerde geboorte- en sterftestatistieken afgeleid. ${ }^{39}$ Het ontbreken van een statistiek omtrent het begraven is vermoedelijk de voornaamste reden waarom de GIP-reeks niet de solide census van 1622 maar een raming van 219.100 inwoners voor 1681-1685 als beginpunt heeft. Die keuze is onmiskenbaar van invloed op de loop van die bevolkingsreeks tot de volkstelling in 1795 met circa 219.500 (=217.00o tot 222.00o) inwoners. De aanwas tussen 1681 en 1795 is per saldo nul, waarmee de tussentijdse migratiesaldi grotendeels van de bekende negatieve geboorteoverschotten afhankelijk zijn. Volgens de opgaven van de auteurs bleven de veranderingen in de bevolkingsomvang vóór 18 oo tot 3 à 4 procent beperkt (zie tabel 5, laatste kolom). Pas tegen 1800 gaat de stagnatie over in een duidelijke neergang, waarbij het inwonertal met meer dan 10 procent onder het gemiddelde van de hele periode daalt. De schrijvers erkennen overigens dat de GIP-methode niet geschikt is om kortere variaties in de migratie te traceren. ${ }^{40}$ De homeostatische bevolkingsreeks, die voor die periode 8,o procent lager dan de GIP-reeks scoort, bezit een meer cyclisch karakter. Voor 1726-1745 en 1766-180o overheersen de stijgende tendensen en het onderscheid met de GIP-reeks is dan niet meer dan 3 procent, soms zelfs minder. Frappant is de overeenkomst tussen die reeksen rond 1730, toen Amsterdam volgens beide met circa 240.000 inwoners zijn grootste omvang vóór 186o bereikte. Er worden voor andere jaren echter ook verschillen tot 15 procent gesignaleerd.

Tabel 5 Vergelijking van de gemiddelde bevolkingsaantallen per periode (volgens homeostatische en GIP methode), 1681-1810

\begin{tabular}{|l|c|c|c|c|c|}
\hline \multirow{2}{*}{ Periode } & \multicolumn{2}{|c|}{ Bevolkingsaantallen (*1.000) } & Verhouding & \multicolumn{2}{|c|}{ Indices (1681-1800 =100) } \\
\cline { 2 - 6 } & Nusteling & $\begin{array}{c}\text { Van Leeuwen } \\
\text { \& Oeppen }\end{array}$ & $\begin{array}{c}\text { VL\&O/ } \\
\text { Nusteling }\end{array}$ & Nusteling & $\begin{array}{c}\text { Van Leeuwen } \\
\text { \& Oeppen }\end{array}$ \\
\hline $1681-1725$ & 201,0 & 231,6 & 1,152 & 94,8 & 100,5 \\
\hline $1726-1745$ & 232,7 & 239,9 & 1,03 & 109,8 & 104,1 \\
\hline $1746-1765$ & 206,8 & 237,8 & 1,15 & 97,6 & 103,2 \\
\hline $1766-1800$ & 223,6 & 226,9 & 1,014 & 105,5 & 98,5 \\
\hline $1801-1810$ & 188,8 & 203,4 & 1,077 & 89,1 & 88,3 \\
\hline $1681-1810$ & 211,9 & 230,4 & 1,087 & 100 & 100 \\
\hline
\end{tabular}

39 Van Leeuwen en Oeppen, 'Reconstructing', 69-71.

40 Ibidem, 9o, 92. 
Tabel 6 Huwelijksfrequentie in relatie tot de homeostatische bevolkingsaantallen, Amsterdam, 1586-1865

\begin{tabular}{|l|c|c|c|}
\hline Periode & Min.-Max. (promille) & Max/Min. & Gemiddelde (promille) \\
\hline $1586-1615$ & $13,8-18,3$ & 1,326 & 15,3 \\
\hline $1616-1650$ & $11,7-15,0$ & 1,282 & 13,57 \\
\hline $1651-1700$ & $10,1-13,5$ & 1,337 & 11,81 \\
\hline $1701-1750$ & $10,5-12,1$ & 1,152 & 10,97 \\
\hline $1751-1810$ & $9,8-12,2$ & 1,245 & 10,98 \\
\hline $1811-1865$ & $8,2-9,6$ & 1,171 & 8,87 \\
\hline
\end{tabular}

In het voorgaande spelen drie kwesties door elkaar heen. Ten eerste, wat is het inwonertal van 219.100 waarmee de GIP-reeks in 1681-1685 begint, waard? Vervolgens, wat valt er te zeggen over de natuurlijke aanwas en migratie? Ten slotte, wat is de onderscheiden cyclische geaardheid van de reeksen? Om met het laatste aspect te beginnen, het lijkt of Van Leeuwen en Oeppen de geringere fluctuaties van de GIP-curve vooral als een defect van de homeostatische methode zien. Naar hun zeggen worden de homeostatische inwonertallen verkregen door huwelijksaantallen - in strijd met de werkelijkheid - te combineren met een constante huwelijksfrequentie. ${ }^{41}$ 'In reality this may simply mean that the marriage rate fluctuated more than allowed for by a method with a constant twenty-year moving marriage rate.' De auteurs drukken zich niet duidelijk uit. Wat is met een constante, maar niettemin over twintig jaar opschuivend huwelijksratio bedoeld? Een constante huwelijksratio verandert niet door het in de tijd te verschuiven. Andere omschrijvingen zijn als verklaring evenmin acceptabel. ${ }^{42}$ De homeostatische methode berust overigens niet op constante huwelijksfrequenties. De gegevens voor alle ondertrouwen (1586-1810) en alle huwelijken (1811-1865) die als promillages van de homeostatische bevolkingstotalen in tabel 6 zijn opgenomen, ${ }^{43}$ laten een grote spreiding in huwelijksfrequenties zien. De tendens van de frequenties is na de zeventiende eeuw - vooral als gevolg van minder hertrouw - dalend. De huwelijksfrequentie beloopt voor 1700-1811 gemiddeld 11 ,o promille tegen 8,9 promille voor $1811-1865$.

\footnotetext{
41 Ibidem, 73, 94-95.

42 Ibidem, 95 (het citaat). Een andere passus, 'a(n assumed) constant marriage rate' (73 en 95), is onjuist en is niet hetzelfde als 'a weighted twenty-year moving average number of marriages' (94), dat trouwens als aanduiding van de methode onvolledig is.

43 Voor (alle) ondertrouw- en huwelijksaantallen in de berekening, zie: Nusteling, Welvaart en werkgelegenheid, 240-241.
} 
Relatief is het verschil 24 procent, dat grotendeels te verklaren is met de overgang in 1810 van de registratie van ondertrouwen naar het vastleggen van binnen de stad gesloten huwelijken. Alle aangeduide perioden kennen echter nog duidelijk onderscheiden minima en maxima, waarvoor tot omstreeks 1700 een globale bandbreedte van 30 procent en daarna van 19 procent geldt.

\section{Sprekende geboorte- en sterftecijfers}

Tabel 7 verschaft een gecomprimeerd overzicht van geboorte- en sterftecijfers die bij de GIP- en de homeostatische bevolkingsreeksen behoren. Voor beide reeksen zijn de gehanteerde geboorte- en sterftereeksen tot 1810 geheel en voor de jaren 1811-1865 nagenoeg hetzelfde. ${ }^{44}$ De bevolkingsreeksen maken het verschil. Het gemiddelde promillage van mijn geboortecijfers bedraagt voor 1681-1810 34,2 tegen 34,9 voor 1811-1865. De grote overeenkomst wijst op continuïteit voor de homeostatische reeks. De GIP-geboortecijfers scoren met respectievelijk 31,4 en 34,o promille voor de periode $1681-181$ o en de jaren $1811^{-}$ 1865 zoals verwacht lager, aangezien de GIP-bevolkingstotalen over het algemeen hoger zijn dan de homeostatische. Het verschil van 2,8 promille in de GIP-geboorteniveaus vóór en na 1811 is naar mijn mening toe te schrijven aan een geringere kwaliteit van de GIP-reeks voor de periode vóór 1811 .

Uitsluitend op basis van de homeostatische inwonertallen zijn voor de jaren 1586-1680 geboortecijfers beschikbaar. Deze zijn met een niveau van 32,8 promille lager dan die na 168 o. Wellicht zijn de lacunes in de doopaantallen van de oudere periode groter dan destijds door mij bij de vaststelling van de statistiek van de geboorten is aangenomen. ${ }^{45}$ Maar het geboorteniveau van 32,8 promille kan toch wel juist zijn, aangezien het correspondeert met de wat gedrukte 'homeostatische' geboortecijfers voor 1726-1 745 en 1766-1 79 o toen er enige bevolkingsaanwas was.

44 Ibidem, 242-243, en Van Leeuwen en Oeppen, 'Reconstructing', 70-71. De geboorte- en sterfteaantallen van Van Leeuwen en Oeppen zijn tot 181 o dezelfde als die van mij, terwijl ze voor de periode 18111865 respectievelijk 3,1 procent hoger en o,9 procent lager zijn dan mijn gegevens. Ten behoeve van gemakkelijkere vergelijkbaarheid zijn die verschillen genegeerd.

45 De doopaantallen zijn om geboorteaantallen te verkrijgen, opgehoogd met 3,1 tot 5,9 procent voor de periode tot 168 o en voor $1681-181$ o met 3,8 tot 13,4 procent. Een forse stijging van de ophoging was nodig vanwege de groeiende populatie joden in Amsterdam, die uiteraard niet waren gedoopt. Nusteling, Welvaart en werkgelegenheid, 242 en 243 , noot 2. 
De bevolkingsgroei zou dan met een positief immigratiesaldo van voornamelijk ongehuwde jongeren de vruchtbaarheid hebben verminderd. Omgekeerd zal bij bevolkingscontractie het vertrek van vooral ongehuwde jongeren tot hogere fertiliteit hebben geleid.

Tabel 7 Geboorte- en sterftecijfers Amsterdam, 1586-1865

\begin{tabular}{|c|c|c|c|c|c|c|}
\hline \multirow[b]{2}{*}{ Periode } & \multicolumn{2}{|c|}{$\begin{array}{l}\text { Geboortecijfers } \\
\text { (promille) }\end{array}$} & \multicolumn{2}{|c|}{$\begin{array}{l}\text { Sterftecijfers } \\
\text { (promille) }\end{array}$} & \multicolumn{2}{|c|}{$\begin{array}{l}\text { Geboorteoverschot } \\
\text { (promille) }\end{array}$} \\
\hline & $\begin{array}{l}\text { Van Leeuwen } \\
\text { \& Oeppen }\end{array}$ & Nusteling & $\begin{array}{l}\text { Van Leeuwen } \\
\text { \& Oeppen }\end{array}$ & Nusteling & $\begin{array}{l}\text { Van Leeuwen } \\
\text { \& Oeppen }\end{array}$ & Nusteling \\
\hline $1586-1616$ & & 32,1 & & & & \\
\hline $1616-1630$ & & 34 & & 51,4 & & $-17,4$ \\
\hline $1631-1660$ & & 32,8 & & & & \\
\hline $1661-1680$ & & 32,5 & & & & \\
\hline $1586-1680$ & & 32,8 & & & & \\
\hline $1681-1700$ & 32,3 & 36 & 33,8 & 37,8 & $-1,5$ & $-1,8$ \\
\hline $1701-1725$ & 29,1 & 34,3 & 30,7 & 36,2 & $-1,6$ & $-1,9$ \\
\hline $1726-1745$ & 31 & 32 & 36,1 & 37,3 & $-5,1$ & $-5,3$ \\
\hline $1746-1765$ & 30,5 & 35,1 & 32 & 36,8 & $-1,5$ & $-1,7$ \\
\hline $1766-1790$ & 31,2 & 32,1 & 36 & 37 & $-4,8$ & $-4,9$ \\
\hline $1791-1810$ & 35 & 36 & 37,4 & 38,4 & $-2,4$ & $-2,4$ \\
\hline $1681-1810$ & 31,4 & 34,2 & 34,3 & 37,2 & $-2,9$ & -3 \\
\hline $1811-1835$ & 32,8 & 34,6 & 35 & 37 & $-2,2$ & $-2,4$ \\
\hline 1836-1865 & 35 & 35,2 & 32,3 & 32,5 & 2,7 & 2,7 \\
\hline $1811-1865$ & 34 & 34,9 & 33,5 & 34,5 & 0,5 & 0,4 \\
\hline
\end{tabular}

De geboorte- en de sterfteaantallen zijn ontleend aan Nusteling, Welvaart en werkgelegenheid, 242-243, de GIP-bevolkingstotalen aan Van Leeuwen en Oeppen, 'Reconstructing', 87 en de homeostatische totalen aan Bijlage 1 van dit artikel.

De statistiek omtrent de mortaliteit is minder volledig dan die voor de fertiliteit. Een doorlopende serie sterftepromillages begint voor Amsterdam vanaf 1681 . Toch kan het stramien dat tabel 7 voor de sterfte laat zien de betrouwbaarheid van de homeostatische inwonertallen vóór 1810 eveneens bevestigen. Berekend op basis van de homeostatische bevolkingsreeks bewoog de mortaliteit zich in 1681-1835 tussen 36,2 tot 38,4 promille bij een gemiddelde van 37,2 , hetgeen hoger en tegelijkertijd uitgesproken stabieler was dan het niveau van gemiddeld 34,5 promille voor de GIP-sterftecijfers. De bandbreedte voor de laatste van 
30,7 tot 37,4 promille is nogal groot. De lage mortaliteit van 30,7 promille voor 1701-1725 en van 32,o promille voor 1746-1765 wijzen mijns inziens op te hoge GIP-ramingen.

Over langere perioden lijkt de mortaliteit tamelijk stabiel te zijn geweest. In het licht van Dordtse sterftecijfers ${ }^{46}$ en verspreide gegevens voor Amsterdam ${ }^{47}$ heerste er tot kort vóór 1680 een hoge sterfte van ruim 5 o promille. Voor de volgende anderhalve eeuw - tot 1835 - laat de homeostatische inwonerreeks, gecombineerd met de dan regelmatige stroom begrafenisaantallen, een aanmerkelijk lager sterfteregime zien van 34 promille. Tegen het midden van de negentiende eeuw zette een verdere daling in die tenslotte in een drastische verandering van het demografisch regime zou uitmonden.

Bij de geboortetekorten in tabel 7 blijken de verschillen tussen de homeostatische en de GIP-promillages gering te zijn. Gemiddeld bedroeg vóór 1810 het tekort bij de homeostatische en GIP-reeksen respectievelijk -3,o en -2,9 promille. Met circa -5,1 promille was in 1726-1745 voor beide het tekort het grootst en in 1746-1765 met circa -1,6 promille het kleinst. Dit contrast tussen twee op elkaar volgende perioden van twintig jaar zou te verklaren zijn met bevolkingsgroei die door contractie gevolgd werd. Bij een eerdere gelegenheid heb ik vastgesteld ${ }^{48}$ dat tussen 1600 en 1675 het migratiesaldo 267.000 migranten bedroeg, waarvan 121.00o personen het zeer hoge sterfteoverschot in die jaren compenseerden en 146.0oo de vermeerdering van het inwonertal droegen. Voor de volgende periode van 1676 tot 1825 , die twee keer zo lang duurde, was er geen noemenswaardige, blijvende aanwas van de bevolking meer. Het migratiesaldo van 75.00o diende nagenoeg geheel om het sterfteoverschot weg te wissen. Na 1835 hebben als gevolg van vermindering van de sterfte de geboortetekorten voorgoed plaats gemaakt voor overschotten. Daarmee zijn we op een punt beland om ons op de inwonerreeksen voor de pre-statistische tijd te richten.

46 H.P.H. Nusteling, E. Havers en Th. van der Weegen, Van de wieg tot het graf. Statistische reeksen voor de demografie van Dordrecht 1574-1811 (Dordrecht 2008) 126 en Nusteling, Welvaart en werkgelegenheid, 242. 


\section{Hoeveel inwoners telde de stad in 1681-1685?}

De GIP-reeks begint met 219.10o inwoners in 1681-1685, waarvoor de homeostatische methode met 189.400 inwoners een bijna 14 procent lagere uitkomst geeft. De suggestie is dat het getal van 219.000 berust op het aantal overledenen in dat interval en een mortaliteit die van een door G. Alter aan de hand van Amsterdamse levensverzekeringen en annuïteiten vastgestelde levensverwachting is afgeleid. ${ }^{49}$ Tabel 8 geeft de levensverwachting van 168 o tot 1700 volgens Alter en de door mij daarmee berekende mortaliteit naast sterftepromillages die met de beschikbare sterfteaantallen en de GIP- en homeostatische bevolkingstotalen voor Amsterdam zijn verkregen. Daaruit blijkt dat voor 219.100 inwoners niet Alters gegevens doorslaggevend waren maar dat dat aantal veeleer op een raming door middel van doopaantallen à la Van der Woude berust. ${ }^{50}$

Tabel 8 Levensverwachting bij geboorte en algemene mortaliteit naar verschillende auteurs, Amsterdam, 1678-1700

\begin{tabular}{|l|c|c|c|c|}
\hline \multirow{2}{*}{ Periode } & Levensverwachting & \begin{tabular}{r} 
Sterfte Promillages \\
\cline { 2 - 3 }
\end{tabular} & $\begin{array}{c}\text { Van Leeuwen } \\
\text { \& Oeppen }\end{array}$ & Nusteling \\
\hline $1678-1682$ & 28,87 jaar & 34,6 & & \\
\hline $1681-1685$ & $(30,55$ jaar) & $(32,7)$ & 35,6 & 41,2 \\
\hline $1683-1687$ & 32,23 jaar & 31 & & \\
\hline $1686-1690$ & $(31,94$ jaar) & $(31,3)$ & 33,4 & 37 \\
\hline $1688-1692$ & 30,44 jaar & 32,9 & & \\
\hline $1691-1695$ & $(31,6$ jaar) & $(31,6)$ & 34,6 & 38,2 \\
\hline $1693-1697$ & 32,77 jaar & 30,5 & & \\
\hline $1696-1700$ & $(32,2$ jaar) & $(31,1)$ & 31,5 & 34,7 \\
\hline $1681-1700$ (gemiddeld) & (31,6 jaar) & 31,6 & 33,8 & 37,8 \\
\hline
\end{tabular}

De cijfers tussen haakjes zijn interpolaties van voorgaande en volgende waarden.

Volgens Alter was in de periode 1681-170o de levensverwachting bij geboorte gemiddeld 31,6 jaar, hetgeen wijst op een sterfte van 31,6 promille $\left(=1000 / 31,6 \mathrm{j} . \mathrm{e}_{\mathrm{o}}\right) \cdot{ }^{51}$ Dezelfde bron leidt tot een mortaliteit voor 1681-

49 Van Leeuwen en Oeppen, 'Reconstructing', 77 (zie experiment 11) en 87.

5 o Ibidem, 84 .

51 Wanneer iedereen bij geboorte 100 jaar te leven heeft, beloopt de sterfte gemiddeld 10 promille (= 1 procent). Bij een levensverwachting van 31,6 jaar is de sterfte 3,165 (= 100 jaar/31,6 jaar) keer zo hoog zijn, dus 31,65 promille. 
1685 van 32,73 promille $(=1000 / 30,55 \text { j.e })_{0}$, hetgeen gecombineerd met 38.955 sterftegevallen voor het interval evenwel geen $219.100^{5^{2}}$ maar 238.50o inwoners oplevert. De feitelijke keuze voor een 9 procent hogere mortaliteit van 35,6 promille krijgt niet meer toelichting dan 'Small differences between GIP-estimates and those based on life annuities are also likely to occur'. ${ }^{53}$ Er zijn redenen genoeg voor twijfel of de annuïteiten niet te eenzijdig zijn samengesteld om de algemene mortaliteit in Amsterdam te berekenen. Annuïteiten waren voor rijkelui bestemd. Het kan zijn dat naar analogie van andere Europese landen pas in de loop van de achttiende eeuw voor de hogere burgerij de levensverwachting gunstiger werd dan die voor minder gefortuneerde stadsgenoten, maar Van Leeuwen en Oeppen gaan voorbij aan Alters voorbehoud dat jonge kinderen bij deze verzekeringen vermoedelijk onvoldoende vertegenwoordigd zijn. ${ }^{54}$ Daarmee is de algemene levensverwachting te gunstig voorgesteld. Indien vanwege hoge sterfte men voor kinderen onder de vijf jaar zelden een annuïteitenverzekering afsloot, dan dient de uit Alters gegevens afgeleide sterfte van 32,7 promille voor 1681-1685 naar ten minste 39,3 promille te worden verhoogd, ${ }^{55}$ waarmee een mortaliteit van 41 promille bij een homeostatische inwonertal van 189.300 voor die jaren redelijk overeenstemt.

\section{Toetsing aan de hand verspreide bevolkingsramingen}

De juistheid van de homeostatische bevolkingstotalen is voor de pre-statistische tijd moeilijk afdoende te bewijzen. Volkstellingen zijn schaars, met slechts twee voor Holland. Extrapolatie volgens de homeostatische methode van het in 1622 getelde inwonertal geeft bijna 175 jaar later voor 1795 , het jaar van de andere telling, een zeer goed resultaat. Naast de toetsen voor de korte termijn in de negentiende eeuw is dat bemoedigend, maar hoe weten we dat de verificatie niet in vage waarschijnlijk-

52 Ibidem, 87.

53 Ibidem, 79 .

54 G. Alter, 'Plague and the Amsterdam annuitant. A new look at life annuities as a source for historical demography', Population Studies 37 (1983) 23-41, met name 36.

55 Naar een Amsterdamse levensverwachtingstabel in 1850-1859 (Van Leeuwen en Oeppen, 'Reconstructing', 78 ) overleed 33 procent van de kinderen in de eerste vijf levensjaren, hetgeen een sterfte van 6,6 procent per jaar impliceert. Die leeftijdscategorie, die in Alters levensverwachtingen buiten zicht blijft, omvatte in 1681-1685 1 o procent van de bevolking (ibidem, 87-88). De van diens gegevens afgeleide jaarlijkse sterfte van 32,7 promille voor $1681-1685$ is daarom met ten minste 6,6 promille $(=6,6$ procent per jaar voor 10 procent van de bevolking) naar 39,3 promille te verhogen. 
heden blijft steken? Na in Welvaart en werkgelegenheid een samenhang van de homeostatische reeks met de economie en de sociale politiek te hebben aangetoond en na de beschouwing hierboven van patronen in het verloop van geboorte- en sterftecijfers lijkt de homeostatische reeks vóór 1800 alleen nog aan de hand van verspreide bevolkingsschattingen te toetsen.

James Surowiecki heeft de stelling geponeerd, dat grote groepen willekeurig geselecteerde personen in doorsnee vaak tot betere oordelen komen dan experts. De spreiding van de leken moet qua achtergrond wel voldoende zijn en hun oordeel behoort onafhankelijk tot stand te zijn gekomen. ${ }^{5}$ Die opvatting bracht mij op de gedachte om van verspreide ramingen gemiddelde inwonertallen voor Amsterdam in de periode 1585 tot $1795^{57}$ te construeren en deze met corresponderende homeostatische en GIP-bevolkingstotalen te vergelijken. Eerst heb ik voor elf onderscheiden jaren of intervallen tussen 1585 en 1670 gemiddelden op basis van vroeger bijeen gesprokkelde ramingen vastgesteld en deze vervolgens aan vergelijkbare homeostatische aantallen gerelateerd. Die verhoudingen zijn ook als absolute afwijkingen in tabel 9 weergegeven, waarbij de cijfers van de afzonderlijke peildata ten slotte tot een gemiddelde voor het gehele tijdvak $15^{8} 5^{-16} 7_{0}$ zijn samengevoegd. Overeenkomstige bewerkingen zijn tevens voor elf peildata in de periode 1680-1 795, waarvoor ook GIP-totalen beschikbaar zijn, in tabel 9 opgenomen.

De elf peildata voor de periode 1680-1795, die als een soort steekproef verkregen zijn, laten de afwijkingen tussen de drie categorieën (verspreide ramingen, homeostatische en GIP-reeksen) zien. Het aantal van zulke afwijkingen groter dan 10 procent is bij Ramingen/Homeo., Ramingen/GIP en Homeo./GIP respectievelijk 2, 5 en 4. Die verdeling vinden we terug in de gemiddelde afwijkingen van 6,6 procent voor Ramingen/Homeo., van 10,1 procent voor Ramingen/GIP, en 7,1 procent voor Homeo./GIP in tabel 9. Het houdt in dat de grotere afwijkingen het meest worden gesignaleerd in de verhoudingen waarvan de GIP-inwonertallen deel uitmaken. Bij nadere beschouwing blijkt een uitsplitsing van de gesignaleerde waarden van onnauwkeurigheid per afzonderlijke categorie mogelijk. Naar de berekening die men in noot 58 vindt toegelicht, bedraagt de afwijking voor de GIP-waarden dooreen genomen 5,2 procent, waarmee ze niet nauwkeuriger zijn dan de ramingen die

56 J. Surowiecki, The Wisdom of Crowds, 2004.

57 Nusteling, Welvaart en werkgelegenheid, 234-235. 
op de oudere literatuur gebaseerd zijn en waarvoor een gemiddelde afwijking van 4,7 procent naar voren komt. De onnauwkeurigheidsmarge voor de homeostatische gegevens bedraagt gemiddeld 1,8 procent. ${ }^{5}$

Tabel 9 Vergelijking van de bevolkingsaantallen van Amsterdam naar verschillende herkomst, 1680-1795

\begin{tabular}{|l|c|c|c|c|c|c|}
\hline \multirow{2}{*}{ Jaartal } & \multicolumn{3}{|c|}{ Verhouding bevolkingsaantallen } & \multicolumn{3}{|c}{ Afwijking bevolkingsaantallen } \\
& $\begin{array}{c}\text { Ramingen/ } \\
\text { Home. }\end{array}$ & $\begin{array}{c}\text { Ramingen/ } \\
\text { GIP }\end{array}$ & $\begin{array}{c}\text { Homeo./ } \\
\text { GIP }\end{array}$ & $\begin{array}{c}\text { Ramingen } \\
\text { vs. Home. }\end{array}$ & $\begin{array}{c}\text { Ramingen } \\
\text { vs. GIP }\end{array}$ & $\begin{array}{c}\text { Homeo. vs. } \\
\text { GIP }\end{array}$ \\
\hline $1680 / 5$ & 1,022 & 0,883 & 0,864 & $2,2 \%$ & $11,7 \%$ & $13,6 \%$ \\
\hline 1700 & 1,078 & 0,952 & 0,883 & $7,8 \%$ & $4,8 \%$ & $11,7 \%$ \\
\hline 1720 & 1,066 & 0,909 & 0,852 & $6,6 \%$ & $9,1 \%$ & $14,8 \%$ \\
\hline 1728 & 0,807 & 0,758 & 0,938 & $19,3 \%$ & $24,2 \%$ & $6,2 \%$ \\
\hline 1732 & 0,888 & 0,885 & 0,996 & $11,2 \%$ & $11,5 \%$ & $0,4 \%$ \\
\hline $1739 / 40$ & 0,918 & 0,917 & 0,999 & $8,2 \%$ & $8,3 \%$ & $0,1 \%$ \\
\hline 1742 & 1,001 & 0,949 & 0,948 & $0,1 \%$ & $5,1 \%$ & $5,2 \%$ \\
\hline $1746 / 50$ & 0,997 & 0,875 & 0,878 & $0,3 \%$ & $12,5 \%$ & $12,2 \%$ \\
\hline 1765 & 0,912 & 0,834 & 0,914 & $8,8 \%$ & $16,6 \%$ & $8,6 \%$ \\
\hline 1780 & 1,071 & 1,037 & 0,968 & $7,1 \%$ & $3,7 \%$ & $3,2 \%$ \\
\hline census 1795 & 1,009 & 1,033 & 1,024 & $0,9 \%$ & $3,3 \%$ & $2,4 \%$ \\
\hline gemid. 1680/1795 & & & & $6,6 \%$ & $10,1 \%$ & $7,1 \%$ \\
\hline gemid. 1585-1670 & & & & $6,1 \%$ & & \\
\hline
\end{tabular}

Uitvoeriger gegevens zijn in Bijlage 2 opgenomen.

58 Voor uitsplitsing van de onnauwkeurigheidsmarges per groep afzonderlijk zijn allereerst de gegeven marges als de wortel van $\left(1,066^{*} 1,101 * 1,071\right)=1,1212$ samen te voegen. De reductie met de wortel 2 is daarbij nodig om de afwijkingen die voor de categorieën onderling gelden, niet dubbel te laten wegen. Wanneer de uitkomst van 1,1212 achtereenvolgens wordt gedeeld door 1,066 voor de afwijking van Ramingen en Homeo samen, door 1,071 voor die van Homeo en GIP en door 1,101 voor de afwijking van Ramingen en GIP, dan blijft steeds die van één categorie over. Aldus verkrijgt men een gemiddelde onnauwkeurigheidsmarge van 5,17 procent (= 1,1212/1,066 minus 1 ) voor GIP, van 4,68 procent $(=1,1212 / 1,071$ minus 1$)$ voor Ramingen en voor de Homeo reeks van 1,83 procent $(=1,1212 / 1,101$ minus 1). De homeostatische reeks is met een afwijking van 1,83 procent niet alleen voor de beschouwde periode prima van kwaliteit, maar dat lijkt ook over nog langere termijn zo te zijn. De afwijking voor Ramingen vs. Homeo was namelijk in $15^{8} 5^{-16}$ o met 6,1 procent zelfs iets gunstiger dan de 6,6 procent voor de nader beschouwde tijd na 168 o. 


\section{Conclusie}

In het voorgaande zijn de opzet en robuustheid beschreven van de methode die gebaseerd is op de idee dat tot het begin van de demografische transitie de vruchtbare huwelijken waarbinnen normaal de kinderen geboren werden, een vaste verhouding toonden ten opzichte van de bevolking als geheel. Vanwege het demografische evenwicht dat is verondersteld, spreken we over de homeostatische methode. Aangetoond is dat berekening van de bevolkingsreeks voor Amsterdam in 1586 tot 1865 in twee delen (vóór en na 1810 met twee verschillende huwelijksreeksen en twee volkstellingen) geen aantasting inhoudt van het principe van de vaste verhouding waarop de methode is gebaseerd. Door twee verschillende maar wel adequate omrekeningsfactoren te hanteren zijn beide huwelijksreeksen onder dezelfde noemer gebracht, waarbij impliciet eenzelfde factor overblijft om de onderling op elkaar afgestemde huwelijksreeksen in inwonertallen om te zetten. De kritiek op de homeostatische methode is daarmee weerlegd.

Doordat die bevolkingsreeks voor Amsterdam gebaseerd is op twee huwelijksreeksen en twee volkstellingen maar onafhankelijk van andere gegevens tot stand is gekomen, kan ze in tegenstelling tot de GIPbevolkingsreeks op allerlei manieren worden getoetst. Zo toont de homeostatistische reeks in zijn geboorte- en sterftecijfers en in zijn migratiesaldo's een eigen regelmaat en daarmee verhelderend karakter. Een vergelijking met de volkstellingen is eveneens gunstig. Ten slotte blijkt de confrontatie van de homeostatische en GIP-inwonertallen met gemiddelden van een aantal andere bevolkingsramingen van verspreide origine voor Amsterdam in de pre-statische tijd bijzonder interessant te zijn. De GIP-reeks scoort ten opzichte van verspreide 'traditionele' schattingen eerder slechter dan beter, de homeostatische reeks komt als aanzienlijk nauwkeuriger naar voren.

Goede bevolkingsgegevens zijn een machtig middel om de samenhang van het historisch gebeuren correct te verstaan - zelfs als men zich tot demografische variabelen beperkt. Een voornaam aspect van de homeostatische methode is dat zij het gemakkelijker maakt bestaande volkstellingen en -ramingen op hun waarde te schatten, zeker wanneer er om andere redenen al aan hun betrouwbaarheid te twijfelen valt. Dat is bijvoorbeeld het geval bij de volkstellingen voor Amsterdam rond 1810, maar vergelijkbare situaties doen zich voor bij de volkstelling van 
Engeland in 1801 en in $1841,{ }^{59}$ de bevolkingsstatistiek van Gregory King voor dat land in 1695 of de berekening van Engelands inwonertal door de Cambridge Group op basis van communicantentellingen van $1676 .{ }^{6 \circ}$ Voor kritisch onderzoek naar de vraag of de sterfte in Ierland tijdens de Ierse hongersnood in de jaren 1840 niet overschat wordt bij onderschatting van de migratie naar Engeland, ${ }^{61}$ blijkt de homeostatische methode evenzeer een passend en nuttig hulpmiddel. ${ }^{62}$

\section{Over de auteur}

Hubert P.H. Nusteling (1934) studeerde onder meer geschiedenis aan de Katholieke Universiteit te Nijmegen. Na werkzaam geweest te zijn bij het сBS en in het middelbaar onderwijs, was hij 25 jaar aan genoemde universiteit verbonden als docent en onderzoeker voor Economische en Sociale Geschiedenis. $\mathrm{Pu}$ blicaties van zijn hand verschenen over de Rijnvaart in de negentiende eeuw en verder over stadsgeschiedenis, historische demografie en bedrijfsgeschiedenis van de zestiende tot in de twintigste eeuw.

E-mail: hphnusteling@xs4all.nl

59 H.P.H. Nusteling, 'English population statistics for the first half of the nineteenth century. A new answer to old questions', Annales de Démographie (1993) 174, 185-186.

6o H.P.H. Nusteling, 'The population of England (1539-1873). An issue of demographic homeostasis', Histoire et Mesure 8 (1993) 67-70.

61 H.P.H. Nusteling, 'How many Irish potato famine deaths? Toward coherence of the evidence', Historical Methods. A Journal of Quantitative and Interdisciplinary History 42 (2009) 70-75.

62 Erkentelijkheid past hier jegens Theo van der Weegen van de Radboud Universiteit Nijmegen. Deze bracht de mij niet alleen tot het gebruik van de computer bij mijn onderzoek, maar hij zorgde destijds ook voor de correcte koppeling van de ondertrouw- en huwelijksreeksen bij de constructie van de bevolkingsreeks van Amsterdam in 1586-1865. Mijn dank geldt echter bovenal mijn liefste, mijn Ans. 
Bijlage 1 Ondertrouw en huwelijken, vruchtbare huwelijken en bevolkingsaantallen Amsterdam, 1581-1865

\begin{tabular}{|c|c|c|c|c|c|c|c|}
\hline \multirow[b]{2}{*}{$\begin{array}{l}\text { Periode } \\
1581-1810\end{array}$} & \multicolumn{3}{|c|}{ Ondertrouwen } & \multicolumn{2}{|c|}{$\begin{array}{c}\text { Vruchtbare } \\
\text { huwelijken (vhi) }\end{array}$} & \multicolumn{2}{|c|}{$\begin{array}{c}\text { Vijfjaarlijkse } \\
\text { bevolkingsaantallen }\end{array}$} \\
\hline & $\begin{array}{c}\text { Eerste } \\
\text { huwelijken }\end{array}$ & $\begin{array}{c}\text { Alle } \\
\text { huwelijken } \\
\text { (eerste en } \\
\text { hertrouw- } \\
\text { huwelijken) }\end{array}$ & $\begin{array}{c}\% \\
\text { Eerste } \\
\text { huwelijken }\end{array}$ & $\begin{array}{c}\text { obv. } \\
\text { Eerste } \\
\text { huwelijken }\end{array}$ & & $\begin{array}{c}\text { obv. } \\
1621-25 \\
\text { (106.500 } \\
\text { inwoners) } \\
\text { en vhi }\end{array}$ & $\begin{array}{c}\text { afwij- } \\
\text { kend in } \\
\text { Welvaart, } \\
240-241 .\end{array}$ \\
\hline $1581-1585$ & 1.205 & 1.754 & 68,7 & & & & \\
\hline $1586-1590$ & 1.838 & 2.676 & 68,7 & 1.426 & & 33.445 & \\
\hline $1591-1595$ & 2.268 & 3.301 & 68,7 & 1.764 & & 41.356 & \\
\hline $1596-1600$ & 2.356 & 3.429 & 68,7 & 2.087 & & 48.946 & \\
\hline $1601-1605$ & 3.446 & 5.462 & 63,1 & 2.540 & & 59.549 & \\
\hline $1606-1610$ & 3.510 & 4.961 & 70,8 & 3.077 & & 72.145 & \\
\hline $1611-1615$ & 4.080 & 5.677 & 71,9 & 3.529 & & 82.738 & \\
\hline $1616-1620$ & 4.762 & 6.818 & 69,8 & 4.034 & & 94.587 & \\
\hline $1621-1625$ & 5.035 & 7.427 & 67,8 & 4.542 & & 106.499 & \\
\hline $1626-1630$ & 6.136 & 9.025 & 68,0 & 5.136 & & 120.442 & \\
\hline $1631-1635$ & 6.322 & 8.879 & 71,2 & 5.776 & & 135.430 & \\
\hline $1636-1640$ & 7.013 & 10.384 & 67,5 & 6.325 & & 148.316 & \\
\hline $1641-1645$ & 7.738 & 10.407 & 74,4 & 6.925 & & 162.377 & \\
\hline $1646-1650$ & 7.484 & 10.141 & 73,8 & 7.372 & & 172.873 & \\
\hline $1651-1655$ & 7.618 & 10.868 & 70,1 & 7.543 & & 176.865 & \\
\hline $1656-1660$ & 8.377 & 11.690 & 71,7 & 7.766 & & 182.109 & \\
\hline $1661-1665$ & 8.887 & 12.396 & 71,7 & 8.220 & & 192.756 & \\
\hline $1666-1670$ & 9.208 & 12.641 & 72,8 & 8.722 & & 204.511 & \\
\hline $1671-1675$ & 8.062 & 11.145 & 72,3 & 8.793 & & 206.179 & \\
\hline $1676-1680$ & 7.247 & 9.776 & 74,1 & 8.245 & & 193.334 & \\
\hline $1681-1685$ & 9.221 & 12.796 & 72,1 & 8.075 & & 189.341 & \\
\hline $1686-1690$ & 8.488 & 10.964 & 77,4 & 8.438 & & 197.866 & \\
\hline 1691-1695 & 8.959 & 11.692 & 76,6 & 8.686 & & 203.684 & \\
\hline $1696-1700$ & 8.717 & 11.114 & 78,4 & 8.801 & & 206.377 & \\
\hline $1701-1705$ & 7.962 & 10.395 & 76,6 & 8.589 & & 201.401 & \\
\hline $1706-1710$ & 8.842 & 11.258 & 78,5 & 8.444 & & 198.004 & \\
\hline $1711-1715$ & 8.429 & 10.565 & 79,8 & 8.506 & & 199.444 & \\
\hline
\end{tabular}




\begin{tabular}{|c|c|c|c|c|c|c|}
\hline \multirow[b]{2}{*}{$\begin{array}{l}\text { Periode } \\
1581-1810\end{array}$} & \multicolumn{3}{|c|}{ Ondertrouwen } & $\begin{array}{c}\text { Vruchtbare } \\
\text { huwelijken (vhi) }\end{array}$ & \multicolumn{2}{|c|}{$\begin{array}{c}\text { Vijfjaarlijkse } \\
\text { bevolkingsaantallen }\end{array}$} \\
\hline & $\begin{array}{c}\text { Eerste } \\
\text { huwelijken }\end{array}$ & $\begin{array}{c}\text { Alle } \\
\text { huwelijken } \\
\text { (eerste en } \\
\text { hertrouw- } \\
\text { huwelijken) }\end{array}$ & $\begin{array}{c}\% \\
\text { Eerste } \\
\text { huwelijken }\end{array}$ & $\begin{array}{c}\text { obv. } \\
\text { Eerste } \\
\text { huwelijken }\end{array}$ & $\begin{array}{c}\text { obv. } \\
1621-25 \\
\text { (106.500 } \\
\text { inwoners) } \\
\text { en vhi }\end{array}$ & $\begin{array}{c}\text { afwij- } \\
\text { kend in } \\
\text { Welvaart, } \\
\text { 240-241. }\end{array}$ \\
\hline $1716-1720$ & 8.785 & 11.122 & 79,0 & 8.581 & 201.204 & \\
\hline $1721-1725$ & 10.193 & 12.843 & 79,4 & 9.018 & 211.464 & \\
\hline $1726-1730$ & 10.367 & 13.289 & 78,0 & 9.717 & 227.849 & \\
\hline $1731-1735$ & 10.354 & 13.326 & 77,7 & 10.188 & 238.892 & \\
\hline $1736-1740$ & 9.683 & 12.577 & 77,0 & 10.191 & 238.955 & \\
\hline $1741-1745$ & 8.313 & 11.116 & 74,8 & 9.602 & 225.163 & \\
\hline $1746-1750$ & 8.599 & 11.467 & 75,0 & 8.907 & 208.859 & \\
\hline $1751-1755$ & 8.532 & 11.220 & 76,0 & 8.598 & 201.604 & \\
\hline $1756-1760$ & 9.075 & 11.787 & 77,0 & 8.656 & 202.967 & \\
\hline $1761-1765$ & 10.042 & 13.046 & 77,0 & 9.114 & 213.714 & \\
\hline $1766-1770$ & 9.682 & 12.457 & 77,7 & 9.581 & 224.655 & \\
\hline $1771-1775$ & 9.022 & 11.690 & 77,2 & 9.576 & 224.536 & \\
\hline $1776-1780$ & 9.751 & 12.770 & 76,4 & 9.447 & 221.507 & \\
\hline $1781-1785$ & 10.488 & 13.718 & 76,5 & 9.722 & 227.970 & \\
\hline $1786-1790$ & 9.428 & 12.144 & 77,6 & 9.931 & 232.861 & \\
\hline $1791-1795$ & 8.842 & 11.385 & 77,7 & 9.599 & 225.093 & \\
\hline $1796-1800$ & 7.852 & 10.268 & 76,5 & 8.905 & 208.815 & 209.020 \\
\hline 1801-1805 & 7.778 & 10.115 & 76,9 & 8.225 & 192.874 & 193.470 \\
\hline $1806-1810$ & 7.745 & 10.071 & 76,9 & 7.878 & 184.718 & 186.080 \\
\hline
\end{tabular}

Cursieve getallen berusten deels op schattingen. Het inwonertal van 106.500 inwoners in 1621-25 is afgeleid van 104.900 inwoners volgens de census van 1622. De ondertrouwen voor eerste huwelijken zijn het aantal personen dat voor het eerst ging trouwen, gedeeld door twee.

In deze tabel zijn geen correcties vanwege buitenechtelijke kinderen doorgevoerd, zoals wel in Welvaart en werkgelegenheid, 240-241 voor de jaren 1796-1810 is gebeurd (zie laatste kolom in deze tabel). Aan die bladzijden zijn ook de gegevens omtrent de ondertrouwen en de huwelijken ontleend, onder vermelding van hun bronnen. 


\begin{tabular}{|c|c|c|c|c|c|c|}
\hline \multirow[b]{2}{*}{$\begin{array}{l}\text { Periode } \\
1811-1865\end{array}$} & \multicolumn{3}{|c|}{ Ondertrouwen } & $\begin{array}{c}\text { Vruchtbare } \\
\text { huwelijken (vhi) }\end{array}$ & \multicolumn{2}{|c|}{$\begin{array}{c}\text { Vijfjaarlijkse } \\
\text { bevolkingsaantallen }\end{array}$} \\
\hline & $\begin{array}{c}\text { Eerste } \\
\text { huwelijken }\end{array}$ & $\begin{array}{c}\text { Alle } \\
\text { huwelijken } \\
\text { (eerste en } \\
\text { hertrouw- } \\
\text { huwelijken) }\end{array}$ & $\begin{array}{c}\% \\
\text { Eerste } \\
\text { huwelijken }\end{array}$ & $\begin{array}{c}\text { obv. } \\
\text { Alle } \\
\text { huwelijken }\end{array}$ & $\begin{array}{c}\text { obv. } \\
1826-30 \\
\text { (202.106 } \\
\text { inwoners) } \\
\text { en vhi }\end{array}$ & $\begin{array}{c}\text { afwij- } \\
\text { kend in } \\
\text { Welvaart, } \\
240-241\end{array}$ \\
\hline $1811-1815$ & 6.199 & 7.245 & 85,6 & 7.680 & 179.133 & 180.940 \\
\hline $1816-1820$ & 7.128 & 8.274 & 86,1 & 7.670 & 178.900 & 182.050 \\
\hline $1821-1825$ & 8.034 & 9.163 & 87,7 & 8.166 & 190.469 & 197.990 \\
\hline $1826-1830$ & & 8.700 & & 8.665 & 202.106 & 202.110 \\
\hline 1831-1835 & & 8.272 & & 8.689 & 202.659 & 201.630 \\
\hline $1836-1840$ & & 9.755 & & 8.797 & 205.192 & 206.310 \\
\hline 1841-1845 & & 9.196 & & 9.150 & 213.414 & 217.540 \\
\hline $1846-1850$ & & 9.842 & & 9.415 & 219.592 & 223.090 \\
\hline 1851-1855 & 8.901 & 10.263 & 86,7 & 9.761 & 227.671 & 229.740 \\
\hline $1856-1860$ & 8.488 & 10.171 & 83,5 & 10.043 & 234.250 & 234.960 \\
\hline $1861-1865$ & 9.233 & 10.832 & 85,2 & 10.319 & 240.690 & 241.950 \\
\hline
\end{tabular}

Cursieve getallen berusten deels op schattingen. Het inwonertal van 1826-30 berust op de census van januari 1828. In verband met de berekening van de vruchtbare huwelijken in de eerste drie periodes na 1810 zijn de aantallen ondertrouwen voor een eerste huwelijk (=aantal personen die voor het eerst gingen trouwen, gedeeld door twee) van de intervallen van 1796 tot 1800, te vermenigvuldigen met een factor 1,00533 om de corresponderende aantallen van alle huwelijken te verkrijgen, die dus nauwelijks verschilden van de eerste huwelijken bij ondertrouw. Deze gegevens zijn nodig om de vruchtbare huwelijken in de jaren 1811-1825 te berekenen, die immers voor alle intervallen in de berekening op huwelijkssluitingen en niet op ondertrouwgegevens mogen steunen.

In deze tabel zijn geen correcties vanwege buitenechtelijke kinderen doorgevoerd, zoals wel in Welvaart en werkgelegenheid, 240-241, waaraan ook de aantallen voor eerste en alle huwelijken zijn ontleend, is gebeurd (zie laatste kolom in deze tabel). Dit leidt tot een verlaging van de inwonertallen voor de periode 1796-1865 van gemiddeld 0,9 procent. 
Bijlage 2 Verhouding tussen bestaande oudere schattingen van inwonertallen voor Amsterdam en de homeostatische en de GIP-reeks

\begin{tabular}{|c|c|c|c|c|c|c|c|c|c|c|}
\hline Jaartal & 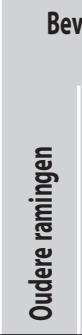 & $\begin{array}{l}\overline{\text { J }} \\
\text { 壱 }\end{array}$ & 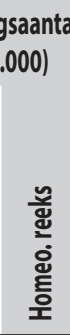 & 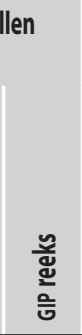 & 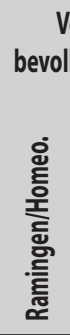 & 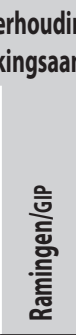 & $\begin{array}{l}\text { 응 } \\
\text { ㅇํ } \\
\text { 오 }\end{array}$ & 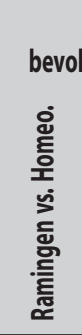 & 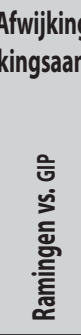 & 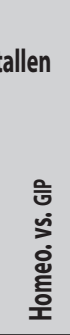 \\
\hline $1585 / 9$ & 32,0 & 3 & 33,5 & & 0,955 & & & $4,5 \%$ & & \\
\hline $1591 / 1600$ & 42,5 & 3 & 44,6 & & 0,953 & & & $4,7 \%$ & & \\
\hline 1605 & 66,1 & 1 & 66,0 & & 1,002 & & & $0,2 \%$ & & \\
\hline 1615 & 93,4 & 2 & 88,6 & & 1,054 & & & $5,4 \%$ & & \\
\hline $1626 / 30$ & 116,3 & 4 & 120,4 & & 0,966 & & & $3,4 \%$ & & \\
\hline $1631 / 35$ & 126,3 & 5 & 135,4 & & 0,933 & & & $6,7 \%$ & & \\
\hline $1636 / 40$ & 130,4 & 5 & 148,3 & & 0,879 & & & $12,1 \%$ & & \\
\hline 1642 & 146,5 & 2 & 162,4 & & 0,902 & & & $9,8 \%$ & & \\
\hline $1651 / 55$ & 152,4 & 5 & 176,9 & & 0,862 & & & $13,8 \%$ & & \\
\hline $1661 / 65$ & 185,5 & 5 & 192,8 & & 0,962 & & & $3,8 \%$ & & \\
\hline 1670 & 200,0 & 1 & 205,3 & & 0,974 & & & $2,6 \%$ & & \\
\hline $1680 / 5$ & 193,5 & 5 & 189,3 & 219,1 & 1,022 & 0,883 & 0,864 & $2,2 \%$ & $11,7 \%$ & $13,6 \%$ \\
\hline 1700 & 220,0 & 2 & 204,0 & 231,1 & 1,078 & 0,952 & 0,883 & $7,8 \%$ & $4,8 \%$ & $11,7 \%$ \\
\hline 1720 & 220,0 & 1 & 206,3 & 242,0 & 1,066 & 0,909 & 0,852 & $6 ; 6 \%$ & $9,1 \%$ & $14,8 \%$ \\
\hline 1728 & 184,0 & 1 & 227,9 & 242,9 & 0,807 & 0,758 & 0,938 & $19,3 \%$ & $24,2 \%$ & $6,2 \%$ \\
\hline 1732 & 212,2 & 2 & 238,9 & 239,9 & 0,888 & 0,885 & 0,996 & $11,2 \%$ & $11,5 \%$ & $0,4 \%$ \\
\hline $1739 / 40$ & 219,3 & 3 & 239,0 & 239,2 & 0,918 & 0,917 & 0,999 & $8,2 \%$ & $8,3 \%$ & $0,1 \%$ \\
\hline 1742 & 225,5 & 1 & 225,2 & 237,6 & 1,001 & 0,949 & 0,948 & $0,1 \%$ & $5,1 \%$ & $5,2 \%$ \\
\hline $1746 / 50$ & 208,3 & 5 & 208,9 & 238,0 & 0,997 & 0,875 & 0,878 & $0,3 \%$ & $12,5 \%$ & $12,2 \%$ \\
\hline 1765 & 200,0 & 1 & 219,2 & 239,9 & 0,912 & 0,834 & 0,914 & $8,8 \%$ & $16,6 \%$ & $8,6 \%$ \\
\hline 1780 & 240,0 & 1 & 224,0 & 231,5 & 1,071 & 1,037 & 0,968 & $7,1 \%$ & $3,7 \%$ & $3,2 \%$ \\
\hline census 1795 & 219,0 & 1 & 217,0 & 212,0 & 1,009 & 1,033 & 1,024 & $0,9 \%$ & $3,3 \%$ & $2,4 \%$ \\
\hline gemiddeld 1585-1670 & 117,4 & 36 & 124,9 & & & & & $6,1 \%$ & & \\
\hline gemiddeld 1680-1795 & 212,9 & 23 & 218,2 & 233,9 & & & & $6,6 \%$ & $10,1 \%$ & $7,1 \%$ \\
\hline
\end{tabular}

De oudere ramingen zijn ontleend aan een overzicht in: Nusteling, Welvaart, 234-235. De waarden onder Afwijking bevolkingsaantallen zijn berekend door de corresponderende waarden onder Verhouding bevolkingsaantallen, indien ze kleiner zijn dan 1,00 van $+1,00$ af te trekken, maar indien groter dan $+1,00$ ze met 1,00 te verminderen. Al de gemiddelden in laatste twee regels van het overzicht berusten op de gegevens in de kolom waartoe ze zelf behoren. 